\title{
Drywall Mud ANd Muddy Doctrine: How Not to Decide a Multiple-Exposure Mesothelioma CaSe
}

\author{
Steve C. Gold*
}

\section{INTRODUCTION}

Courts have a long history of stuffing policy considerations into the causation element of tort claims. ${ }^{1}$ High stakes and causal complexity especially elicit such doctrinal misdirection. Toxic tort claims exemplify these traits as much as any type of claim in contemporary tort law. So it comes as no surprise to find judicial policy preferences at or just below the surface in many court opinions that nominally address only whether the plaintiff has proven that the defendant caused the plaintiff's harm. ${ }^{2}$

Judicial decisions have consequences. Stare decisis and the influence exerted by some courts magnify the effects. A court sets a precedent in response to a perceived policy imperative. The precedent is then applied (perhaps borrowed by another jurisdiction) in a second case that it doesn't fit quite as well and is then extended to a third case with unexpected, unjust, or unintelligible results. So it comes as no surprise that when courts misapprehend or misuse factual causation principles, practical concerns are as much at stake as is the theoretical coherence of doctrine.

Scholarship has-or should have-consequences, too. Hard problems and novel issues stimulate academic research. Toxic torts have presented plenty of both, and factual causation has proven to be the most durable, controversial, and intractable difficulty in toxic tort cases. So it comes as no surprise that toxic tort causation has generated a sizable body of legal scholarship, some of which has

* Professor of Law and Judge Raymond J. Dearie Scholar, Rutgers Law School, Rutgers University-Newark. I thank Dean Andrew Klein, Professor Xuan-Thao Nguyen, and the editors of the Indiana Law Review for the opportunity to participate in this symposium. I acknowledge in particular the gracious care provided by Timothy Cochren during and after the symposium. This article benefited from the insights about toxic tort causation of Michael D. Green, who also participated in the symposium, and of Joseph Sanders. Kylie Huff provided invaluable research assistance. Sylviane Gold made many helpful editorial suggestions. Jennifer Aley supplied motivation, encouragement, and proofreading. Errors are my own.

1. See Restatement (Third) of Torts: Liab. for Physical \& Emotional Harm ch. 6, Special Note on Proximate Cause (2010) (explaining how historic use of "proximate cause" and "legal cause" tended to obscure the distinction between causation as a matter of fact and limits on the scope of liability as a normative matter).

2. See, e.g., Gen. Elec. Co. v. Joiner, 522 U.S. 136, 148 (1997) (Breyer, J., concurring) (exhorting courts to be especially vigilant to prevent "powerful engine of tort liability" from destroying innocent chemicals); Lucinda M. Finley, Guarding the Gate to the Courthouse: How Trial Judges Are Using Their Evidentiary Screening Role to Remake Tort Causation Rules, 49 DePaul L. Rev. 335, 362 (1999) (criticizing Justice Breyer's Joiner concurrence and other court opinions for making policy decisions in the guise of determining admissibility of expert testimony on causation). 
found its way into judicial opinions. ${ }^{3}$

In this Article, I explore these phenomena-the injection of normative judgments into factual causation issues, the incoherent application of precedent, and the interaction of legal scholarship with judicial decision-making - through analysis of a 2014 decision by the Supreme Court of Texas. In Bostic v. GeorgiaPacific Corp. ${ }^{4}$ a majority of the Supreme Court of Texas rendered judgment in favor of the defendant (a company that had manufactured and sold asbestoscontaining drywall mud ${ }^{5}$ ) because, the court held, the plaintiffs (survivors of a man who died of mesothelioma) failed to introduce sufficient causation evidence.

In Part I, I describe the factual and procedural setting of Bostic and situate the case among other toxic tort claims, legal models of causation, and scientific knowledge of mesothelioma. In Part II, I argue that the majority opinion in Bostic is internally inconsistent, applies different causal models to the same set of facts, and fundamentally misapprehends its sources, producing deeply flawed holdings that contradict elementary causation principles-most notably the principle that a tortfeasor's act can be a factual cause of harm by combining with the acts of other tortfeasors.

Many of Bostic's roots lie deep in the heart of a much earlier case, Merrell Dow Pharmaceuticals, Inc. v. Havner. ${ }^{6}$ In Part III, I discuss the court's path from Havner to Bostic, which yields insights about the evolution of legal doctrine through common-law judging, about the way judges read legal scholarship, and about the way legal scholars read court opinions.

Bostic is a poor resolution of a recurring problem by an influential court. ${ }^{7}$ The confusion evident in the decision is not limited to the Lone Star State. The lessons of Bostic may be useful to courts and scholars far beyond Texas.

3. For a few guides to this large body of literature, see RESTATEMENT (THIRD) OF TORTS: LiAB. FOR PHysicAl \& EMOTIONAL HARM $\S 28 \mathrm{cmt}$. c reporters' note (2010); Michael D. Green et al., Reference Guide on Epidemiology, in Federal Judicial Center, Reference Manual on SCIENTIFIC Evidence 549, 630-32 (3d ed. 2000); Bernard D. Goldstein \& Mary Sue Henifin, Reference Guide on Toxicology, in FEDERALJUdicIALCENTER, REFERENCE MANUAL ON SCIENTIFIC EvIDENCE 633, 685 (3d ed. 2000). For judicial opinions discussing some of this literature, see, e.g., In re “Agent Orange” Product Liability Litigation, 597 F. Supp. 740 (E.D.N.Y. 1984), aff'd, 818 F.2d 145 (2d Cir. 1987); Merrell Dow Pharmaceuticals, Inc. v. Havner, 953 S.W.2d 706 (Tex. 1997).

4. 439 S.W.3d 332 (Tex. 2014).

5. 'Joint compound, sometimes called 'drywall mud,' is used to connect and smooth the seams of adjoining pieces of drywall, also called sheetrock, and to cover nail heads on sheets of drywall." Georgia-Pacific Corp. v. Bostic, 320 S.W.3d 588, 591 n.2 (Tex. App. 2010), aff'd, 439 S.W.3d 332 (Tex. 2014).

6. Havner, 953 S.W.2d at 706.

7. For one example of the Supreme Court of Texas's influence, see Estate of George v. Vermont League of Cities \& Towns, 993 A.2d 367, 377-78 (Vt. 2010) (relying heavily on Havner to hold that "the trial court did not abuse its discretion in considering a relative risk greater than 2.0 as a reasonable and helpful benchmark"). 


\section{Situating Bostic In The Toxic Tort Universe}

\section{A. The Factual Setting}

Timothy Bostic died at the age of forty from mesothelioma, ${ }^{8}$ an "invariably fatal" cancer of the pleural or peritoneal lining. ${ }^{10}$ Mesothelioma is generally considered a "signature disease" of exposure to certain types of asbestos. ${ }^{11}$ Bostic's survivors sued forty defendants, alleging the defendants were liable under negligence and products liability theories for exposing Bostic to asbestos and causing his disease and death. ${ }^{12}$ The claims against all defendants except Georgia-Pacific Corp. were settled or dismissed before trial. ${ }^{13}$

The nature of Bostic's exposure to asbestos, understandably, attracted considerable evidentiary development at trial. ${ }^{14}$ The proof, as described by the Supreme Court of Texas, established several sources of asbestos fibers that Bostic inhaled:

- Exposure during childhood to asbestos in drywall joint compound products (including some manufactured by Georgia-Pacific) when he helped his father, Harold, on do-it-yourself home projects. Bostic mixed dry joint compound with water to make drywall mud, sanded surfaces to which joint

8. Bostic, 439 S.W.3d at 336.

9. Fairchild v. Glenhaven Funeral Servs. Ltd., [2002] UKHL 22 [7], [2002] 1 A.C. 32 (appeal taken from Eng.).

10. Bostic, 439 S.W.3d at 337 n.4; see Joyce K. Thompson et al., Malignant Mesothelioma: Development to Therapy, 115 J. Cellular Biochemistry 1, 1 (2014).

11. Bostic, 439 S.W.3d at 367 (citing testimony by plaintiff's expert that "only other known cause" of mesothelioma "is radiation treatment for certain types of cancer"); In re Asbestos Litig., 900 A.2d 120, 132 (Del. Super. Ct. 2006) ("[B]ackground incidence rate [of mesothelioma] is basically zero."); Joseph Sanders, The "Every Exposure” Cases and the Beginning of the Asbestos Endgame, 88 Tul. L. REv. 1153, 1155 (2014). Defense attorneys have sometimes argued in court and in print that "a significant number" of mesotheliomas are not caused by asbestos exposure. Mark A. Behrens, What's New in Asbestos Litigation?, 28 Rev. LiTig. 501,527 (2009). However, the assertion is difficult to support because everybody is exposed to some amount of asbestos and very small quantities of asbestos may cause mesothelioma in some people. See Becker v. Baron Bros., 649 A.2d 613, 618 (N.J. 1994) (plaintiff's expert believed apparently idiopathic cases of mesothelioma could be caused by asbestos in the atmosphere); Bostic, 439 S.W.3d at 376 (dissenting opinion) (describing expert testimony that small amounts of chrysotile asbestos fibers are capable of causing genetic errors that eventually result in mesothelioma); Jinfei Xu et al., Germline Mutation of Bapl Accelerates Development of Asbestos-Induced Malignant Mesothelioma, 74 CANCER RES. 4388, 4389, 4395-96 (2014) (reporting experimental results consistent with the hypothesis that a genetic mutation makes individuals more susceptible to mesothelioma after even low levels of asbestos exposure, rather than the hypothesis that the mutation causes individuals to develop mesothelioma even without exposure to asbestos).

12. Bostic, 439 S.W.3d at 336.

13. Georgia-Pacific Corp. v. Bostic, 320 S.W.3d 588, 590 (Tex. App. 2010), aff'd, 439 S.W.3d 332 (Tex. 2014).

14. Id. at 592-94. 
compound had been applied, and swept up dust created during the projects. ${ }^{15}$

- Exposure during childhood and adolescence to "take home" asbestos on Harold's work clothes, resulting from Harold's occupational exposure to asbestos while employed at Knox Glass Company. Because Bostic's parents divorced when Bostic was nine years old, this exposure was smaller than it might otherwise have been. ${ }^{16}$

- Exposure during adolescence in two summers of work at Knox Glass, parts of which were spent in the "hot end" of the plant. At Knox Glass, Bostic cut asbestos cloth, removed and replaced asbestos from machines, and cleaned up after asbestos pipe insulation repairs, all without respiratory protection. ${ }^{17}$

- Exposure during adolescence in two summers of construction work at Palestine Contractors. Bostic worked as a welder's assistant and sometimes removed asbestos-containing pipe insulation and gaskets. ${ }^{18}$

- Exposure during adolescence or adulthood while performing do-it-yourself repairs on automobile brakes and clutches. ${ }^{19}$ Bostic estimated he did four brake jobs a year and ten clutch jobs during his lifetime. ${ }^{20}$

- Exposure during adulthood while performing do-it-yourself remodeling work. Bostic used roofing shingles, floor tiles, and ceiling tiles that contained asbestos. This work did not involve any Georgia-Pacific product that contained asbestos. ${ }^{21}$

- Exposure throughout life to asbestos fibers in the ambient air, not capable of being linked to any particular asbestos-containing product. Such "background" exposure is universal. ${ }^{22}$

15. Id. (describing testimony about specific home improvement projects in detail, including gaps in Harold's recollection); Bostic, 439 S.W.3d at 353, 369 (Lehrmann, J., dissenting) (describing Harold's testimony that he used Georgia-Pacific joint products " 98 percent of the time" and that he and Timothy had used them "many, many, many times"). These opinions show that the number of projects during which Bostic was exposed to asbestos from Georgia-Pacific's products was a matter of dispute and subject to varying interpretations of the testimony. Of course, if a court had been able to conclude that there was no evidence from which a reasonable jury could conclude that Bostic had ever been exposed to asbestos from Georgia-Pacific's products, dismissing the claims against Georgia-Pacific would have been easy.

16. Bostic, 439 S.W.3d at 369 (Lehrmann, J., dissenting).

17. Id.

18. Id. at 354 (no mention of frequency); id. at 369 (Lehrmann, J., dissenting) ("some of the pipes"); id. at 379 ("intermittent"); Georgia-Pacific, 320 S.W.3d at 595 ("three to four times a week").

19. Bostic, 439 S.W.3d at 354 (no discussion of frequency).

20. Georgia-Pacific, 320 S.W.3d at 595 ("when he was older," Bostic did such work; four brake jobs a year and fewer than ten clutch jobs in his lifetime).

21. Id.; Bostic, 439 S.W.3d at 354 (no discussion of frequency).

22. Bostic, 439 S.W.3d at 339 (quoting Flores v. Borg-Warner Corp., 232 S.W.3d 765 (Tex. 2007) (quoting plaintiff's expert)); id. (quoting one of Bostic's expert witnesses: “"[w]e all have some asbestos' in our lungs"); see also Sienkiewicz v. Greif, [2011] UKSC 10 [4], [2011] 2 A.C. 229 (appeal taken from Eng.) (Lord Phillips) (stating that plaintiff's occupational exposure to 
The plaintiffs persuaded two juries that Georgia-Pacific was liable for Bostic's death. ${ }^{23}$ The second jury apportioned liability between Georgia-Pacific and Knox Glass, assigning seventy-five percent of the liability to Georgia Pacific. ${ }^{24}$ After post-trial skirmishing, the trial court entered judgment awarding plaintiffs nearly seven million dollars in compensatory damages and nearly five million dollars in punitive damages ${ }^{25}$ Georgia-Pacific persuaded two appellate courts, for reasons explained below, ${ }^{26}$ to reverse the trial court judgment and render judgment that plaintiffs take nothing. ${ }^{27}$

The above synopsis of Bostic's asbestos exposure immediately distinguishes his claim from those of the generation of claimants that preceded him, the boilermakers and pipefitters who worked for years or decades in air where asbestos dust was "like snow." ${ }^{28}$ By comparison, Bostic's overall exposure to asbestos from identifiable sources was relatively low. ${ }^{29}$

As Joseph Sanders has observed, mesotheliomas in individuals who experienced relatively low exposure constitute an increasing proportion of newly-diagnosed cases of asbestos-related disease in the United States and therefore an increasing proportion of possible new claims. ${ }^{30}$ In part, this is because use of and exposure to asbestos have declined dramatically in the United States since the 1970s. ${ }^{31}$ Many of the heaviest occupational exposures occurred

asbestos, as an office worker at a manufacturing facility, was shown to have increased her total exposure by only $18 \%$ above ambient levels).

23. Georgia-Pacific, 320 S.W.3d at 590-91. After the first jury verdict, the trial judge, for reasons not explained in the appellate decisions, ordered the plaintiffs to agree to remit certain damages or to elect a new trial on all issues. Id. The plaintiffs chose a new trial and prevailed again. Id.

24. Id. at 591. As described above, Bostic was exposed to asbestos fibers during his summer employment at Knox Glass as well as asbestos fibers carried home on his father's work clothes when Bostic's father worked at Knox Glass. See supra text accompanying notes 16-22.

25. Georgia-Pacific, 320 S.W.3d at 591.

26. See infra Part II.

27. Bostic, 439 S.W.3d at 536 (affirming court of appeals' rendered take-nothing judgment); Georgia-Pacific, 320 S.W.3d at 590 (reversing trial court judgment).

28. For instances of this description, see, e.g., ACandS, Inc. v. Asner, 657 A.2d 379, 384 (Md. Ct. Spec. App. 1995) (quoting testimony of coworker of electrician who worked in a shipyard during World War II and died of mesothelioma: "it was always coming down. It was like snow"), rev'd, 686 A.2d 250 (Md. 1996); Peek v. SKW/Clinton, 855 P.2d 415, 419 (Alaska 1993) (noting that several coworkers of pipefitter who died of mesothelioma testified that "asbestos was "like snow' in the air on several jobs”); Wagner v. Bondex Int'l, Inc., 368 S.W.3d 340, 354 (Mo. Ct. App. 2012) (noting testimony that carpenter who cut drywall and ceiling tile was "regularly subjected to clouds of Bondex joint compound asbestos dust that fell like 'snow' over a period of many years").

29. See generally Bostic, 439 S.W.3d 332.

30. Sanders, supra note 11 , at 1182-83.

31. S. Jane Henley et al., Mesothelioma Incidence in 50 States and the District of Columbia, United States, 2003-2008, 19 InT'L J. Occupational EnVtl. Health 1, 1 (2013) (noting decline 
decades ago and the cohort that experienced those exposures is dwindling as age and disease take their toll. ${ }^{32}$ The lower levels of exposure often seen in more recent decades may not be sufficient to cause asbestosis ${ }^{33}$ and may take longer to cause mesothelioma. ${ }^{34}$ Thus, "we should expect that as years go by individuals with lesser exposure to asbestos dust will comprise an increasingly greater percentage of new mesothelioma cases." ${ }^{35}$

Not only was Bostic's overall exposure to asbestos relatively modest; his exposure to fibers from Georgia-Pacific's products was only a fraction of that. ${ }^{36}$ That presented a problem: how to prove specifically that fibers from GeorgiaPacific's joint compound were a cause-in-fact of Bostic's mesothelioma, considering that Bostic was also exposed to other sources of asbestos.

The multiple-exposure problem for asbestos plaintiffs is not new. To the contrary, exposure to asbestos-containing products sold by more than one manufacturer has been the norm since the first successful asbestos claim. ${ }^{37}$ Nor is the multiple-exposure problem limited to cases of modest or occasional exposures. ${ }^{38}$ In early cases brought by heavily exposed plaintiffs, most courts

in use of asbestos); $i d$. at 4 (explaining that mesothelioma incidence correlates with degree of asbestos use in cross-country comparisons); see also U.S. Federal Bans on Asbestos, U.S. EPA, www2.epa.gov/asbestos/us-federal-bans-asbestos [http://perma.cc/7N62-8ZVB] (last visited Mar. 31,2015 ) (describing federal statutory and regulatory prohibitions on certain asbestos products dating from as early as 1973).

32. Henley et al., supra note 31 , at 6 ("US mesothelioma incidence rates were highest among older men and women who were probably exposed to asbestos before ... efforts were undertaken to limit exposure."); Sanders, supra note 11, at 1182-83 (noting that some exposures, such as "exposures in navy shipyards in World War II, were so long ago that most people who were exposed are deceased," and also that workers now becoming ill as a result of such exposures "can find few nonbankrupt defendants to sue").

33. Sanders, supra note 11, at 1157-58 (describing asbestosis as a cumulative disease caused by prolonged exposure to asbestos and made more severe by greater total exposure).

34. A. Reid et al., Mesothelioma Risk After 40 Years Since First Exposure to Asbestos: A Pooled Analysis, 69 THORAX 843, 848 (2014) ("Lower asbestos exposure has been shown . . . to be associated with a longer latency period.").

35. Sanders, supra note 11, at $1155 \mathrm{n} .16$ (explaining that this expectation would hold even if all asbestos exposure were to cease, because the greater the exposure, the shorter the latency period for mesothelioma).

36. Georgia-Pacific Corp. v. Bostic, 320 S.W.3d 588, 598-602 (Tex. App. 2010), aff'd, 439 S.W.3d 332 (Tex. 2014).

37. See Borel v. Fibreboard Paper Prods. Corp., 493 F.2d 1076, 1086, 1094 (5th Cir. 1973) (holding, where plaintiff with asbestosis and mesothelioma alleged exposure to eleven defendants' asbestos products, that if evidence showed that plaintiff was exposed to a defendant's products "the jury could find that each defendant was the cause in fact of some injury to Borel" although "it is impossible, as a practical matter, to determine with absolute certainty which particular exposure to asbestos dust resulted in injury").

38. See, e.g., id. at 1081 (plaintiff Borel worked as an industrial insulation worker for thirtythree years); Lohrmann v. Pittsburgh Corning Corp., 782 F.2d 1156, 1158 (4th Cir. 1986) 
declined to preclude recovery simply because more than one defendant had provided the harmful product, even though no method exists to determine which fibers initiated or promoted a cancer or whence those fibers came. ${ }^{39}$ Instead, in response to the "rock of uncertainty" such cases presented,${ }^{40}$ courts fashioned a number of doctrinal mechanisms that allowed plaintiffs to recover and that also, over time, increasingly permitted at least some distinctions between exposures to defendants' products that would and would not be deemed "causal." 41

The recent prevalence of claims based on the coincidence of low overall asbestos exposures and multiple, individually small exposures has put pressure on these doctrinal mechanisms, however. A number of courts, including the Supreme Court of Texas in a 2007 asbestosis case, ${ }^{42}$ have rejected plaintiffs' causation theories in cases involving exposure to relatively small defendantspecific or aggregate amounts of asbestos. ${ }^{43}$ Bostic is the Supreme Court of Texas's contribution to this trend in a mesothelioma case, but much of it makes no doctrinal sense.

Although, in my view, the dissent overall has the better of the argument in Bostic, my critique of Bostic does not depend on a belief that the court reached the wrong result. Nor does it depend on a belief that, as a general matter, mesothelioma claims based on non-occupational, relatively low exposures should succeed. It is possible to believe that it is better to protect defendants who supplied consumer products containing asbestos from liability than it is to compensate plaintiffs who used those products and developed mesothelioma-and also to believe that the majority's reasoning in Bostic is

(describing how claim by plaintiff with asbestosis who worked as a pipefitter in a shipyard for thirty-nine years "followed the usual course of the plaintiff attempting to prove contact with asbestos-containing products of all [seven] defendants" that went to trial of an original nineteen defendants); id. at 1162-63 (describing case as "typical of this pattern" and holding that "[t]o support an inference of substantial causation from circumstantial evidence, there must be evidence of exposure to a specific product on a regular basis over some extended period of time in proximity to where the plaintiff actually worked"); Rutherford v. Owens-Illinois, 941 P.2d 1203, 1207-08 (Cal. 1997) (explaining that plaintiff diagnosed with lung cancer after more than forty years of occupational exposure to asbestos sued nineteen defendants).

39. See, e.g., Borel, 493 F.2d at 1096 (holding manufacturers of insulation containing asbestos jointly and severally liable).

40. Sienkiewicz v. Greif, [2011] UKSC 10 [7], [2011] 2 A.C. 229 (appeal taken from Eng.) (Lord Bingham of Cornhill).

41. See generally Sanders, supra note 11, at 1161-66 (tracing developments from Borel's individisible-injury, joint-and-several liability approach to Lohrmann's frequency-regularityproximity test to Rutherford's "risk rule"); Jane Stapleton, Two Causal Fictions at the Heart of U.S. Asbestos Doctrine, 122 L. Quarterly Rev. 189, 191 (2006); Joseph Sanders, Risky Business: Causation in Asbestos Cancer Cases (and Beyond?), in PERSPECTIVES ON CAUSATION 11, 15-30 (Richard Goldberg ed., 2011) (tracing lineage of cases in United States and United Kingdom).

42. Flores v. Borg-Warner Corp., 232 S.W.3d 765 (Tex. 2007).

43. Sanders, supra note 11 , at 1176-82 (describing decisions favoring defendants and the absence of a unifying rationale among them). 
beyond salvation. If Bostic rests on a policy preference-if a majority of the Supreme Court of Texas simply concluded that it is time for asbestos litigation to end - the majority did not express that judgment openly but implemented it by distorting the concept of causation-in-fact. If the Bostic majority did not want to make such a policy judgment, it failed to fashion a causation rule that truly balances the interest of defendants in not being liable for harms they did not cause with the interest of plaintiffs in being compensated for wrongfully inflicted harm that cannot definitively be linked to any particular exposure. Bostic's approach, if replicated in other jurisdictions and extended to other contexts, will wreak havoc with the logic of cause-in-fact doctrine.

\section{B. Legal and Biological Models of Causation}

1. Legal Models of Causation.-The familiar tort law test for factual causation asks: but for the defendant's tortious conduct, would the plaintiff's harm not have occurred $?^{44}$ A but-for cause is necessary, and appears sufficient, to bring about the plaintiff's harm. Of course the focus on the defendant's conduct obscures the fact that no harm is caused by a single sufficient cause, so it is more appropriate to think of a causal set of circumstances that together produce the plaintiff's harm. Each necessary element of such a causal set is one of innumerable but-for causes of a plaintiff's harm; all are concurring or contributing causes of the harm. ${ }^{45}$ More than one concurring cause may be tortious, as when a negligently prescribed drug weakens a patient's immune system and the patient, who would otherwise have fought off the infection, is overcome after consuming food that was contaminated with a pathogen when sold. In a toxic tort context, a concurring cause model accepts the possibility that the tortious exposure to the defendant's toxin combined with other causes to produce disease. A concurring cause model might consider, for example, that a plaintiff's genetic susceptibility to DNA damage, exposure to the sun, and wrongful dermal exposure to a chemical carcinogen all were necessary to the plaintiff's development of skin cancer.

But sometimes potential causes are mutually exclusive. If two negligent hunters simultaneously fire in the direction of a plaintiff who is struck by only one bullet, only the hunter who fired that bullet actually caused the plaintiff's injury and ballistics testing might be able to resolve the factual causation question. ${ }^{46}$ In the toxic torts context, a competing cause model posits that one of

44. Restatement (Third) OfTorts: Liab. For Physical \& Emotional Harm § 26 (2010).

45. Id. $\$ 26 \mathrm{cmt}$. g. This model is generally consistent with the "NESS" (Necessary Element of a Sufficient Set) test developed by Richard Wright. See generally Richard W. Wright, Causation in Tort Law, 73 CALIF. L. ReV. 1735, 1788-1803 (1985) (explaining the NESS test); Richard W. Wright, The NESS Account of Natural Causation: A Response to Criticisms, in PERSPECTIVES ON CAusation (Richard Goldberg ed., 2011).

46. If the bullet's source cannot be identified, a court may use the doctrine of alternative liability to shift the burden of proof on causation. Summers v. Tice, 199 P.2d 1 (Cal. 1948). Even if the bullet's source can be identified, in an appropriate case a court might use a doctrine such as 
several potential causes was the actual sine qua non to a plaintiff's harm. A competing cause model might consider, for example, that a plaintiff's development of skin cancer resulted from the plaintiff's genetic predisposition to cancer or exposure to the sun or wrongful dermal exposure to a chemical carcinogen.

And other times multiple causes overdetermine the harm. If two negligent hunters simultaneously fire in the direction of a plaintiff who is struck in the heart by both bullets, each hunter's act (with the set of other causes that brought the three to such a fateful pass) is an independently sufficient cause of plaintiff's harm. A multiple sufficient cause model treats both hunters as causes-in-fact of the harm. ${ }^{47}$ In the toxic tort context, a multiple sufficient cause model posits that the plaintiff's disease would have resulted independently from any of several potential causes. A multiple sufficient cause model might consider, for example, that a plaintiff's development of skin cancer would have resulted from the plaintiff's genetic predisposition to cancer as well as from exposure to the sun as well as from wrongful dermal exposure to a chemical carcinogen, each even in the absence of the other two causes.

In the three skin cancer examples given above, the chemical is described as a carcinogen. This assumption limits the above examples to the toxic tort issue of specific causation - whether the defendant's wrongful exposure of the plaintiff to a toxic substance caused the particular case of disease afflicting the plaintiff, in light of the fact that the same disease may occur in people never exposed to the substance. ${ }^{48}$ If the carcinogenicity of the chemical had been in doubt, the examples would also have involved a problem of general causation or agentdisease causation-whether exposure to the defendant's substance has the biological capacity to cause the plaintiff's disease or whether any coexistence of exposure and disease is purely coincidental. ${ }^{49}$

Also, in the three skin cancer examples given above, the potential causes of the plaintiff's disease were qualitatively different: genetics, solar radiation, or chemical carcinogen. But the concurring, competing, and multiple sufficient cause models all could potentially be applied to groups of potential causes that are qualitatively similar, such as exposure to the same toxic agent from different sources created by different parties-as was the case in Bostic. Evaluating the Bostic majority's choices of legal causation model requires consideration of the biological model of causation that applied in the case.

2. The Biological Model of Mesothelioma Causation by Asbestos Exposure: Concurrent Risk Contribution.- The parties to Bostic disputed much, but the record of the Supreme Court of Texas proceedings reveals very little disagreement about the current state of biological knowledge of mesothelioma causation by asbestos exposure. At least for purposes of the appeal, the parties

concert of action to hold both shooters liable. See RESTATEMENT (SECOND) OF TORTS $§ 876$ (1966).

47. Restatement (ThiRd) ofTorts: Liab. FOR Physical \& EMOtional Harm § 27 (2010).

48. Id. $\S 28 \mathrm{cmt}$. c.

49. Id. 
effectively agreed that asbestos causes pleural mesothelioma ${ }^{50}$ and caused Bostic's pleural mesothelioma. ${ }^{51}$

Plaintiffs' experts, in apparently undisputed testimony, described the process by which inhaled asbestos fibers reach mesothelial tissue, where a fiber can damage a cell's genetic material; the accumulation of such damage can lead to the cell's malignant transformation. ${ }^{52}$ When, usually many years after initial exposure to asbestos, a patient is diagnosed with malignant mesothelioma, it is impossible to identify the fiber or fibers that interacted with the DNA during any of these genetic changes ${ }^{53}$ or to distinguish the sources of fibers of similar types that are found in the patient's tissue..$^{54}$

Mesothelioma is not an inevitable consequence of asbestos exposure, however. ${ }^{55}$ Exposure thus creates a risk, but not the certainty, of disease. Even

50. Bostic v. Georgia-Pacific Corp., 439 S.W.3d 332, 336 (Tex. 2014) ("There is no dispute that asbestos, when breathed into the lungs, can cause mesothelioma."). This article uses "asbestos" as a term of convenience, glossing over distinctions, which were not important to the Bostic decision, between various asbestiform minerals such as chrysotile, amosite, tremolite, or crocidolite. See Georgia-Pacific Corp.'s Brief on the Merits at 6 n.8, Bostic v. Georgia-Pacific Corp., 439 S.W.3d 332 (Tex. 2014) (No. 10-0775) ("Georgia-Pacific contends that chrysotile asbestos [the type found in Georgia-Pacific's joint compound] does not cause mesothelioma; however, for purposes of this appeal, Georgia-Pacific did not challenge the assumption that exposure to chrysotile can cause mesothelioma.").

51. Georgia-Pacific Corp.'s Brief on the Merits at 4, supra note 50 ("Mesothelioma is a relatively rare cancer whose only known environmental cause is exposure to asbestos."). GeorgiaPacific's brief never admitted that asbestos caused Bostic's disease but never contested that fact either, instead emphasizing the "multiple sources" of Bostic's exposure to asbestos. Id.

52. Bostic, 439 S.W.3d at 368 (Lehrmann, J., dissenting). Even with this understanding, scientists do not yet know precisely what all the various genetic disruptions are or how asbestos causes them. See Thompson et al., supra note 10, at 1 ("The molecular pathogenesis of [malignant mesothelioma] is still an elusive multifactorial event involving multiple mechanisms."); Xu et al., supra note 11, at 4388 (identifying several genetic changes implicated in mesothelioma tumorigenesis "to date").

53. Bostic, 439 S.W.3d at 344 ("[E]stablishing which fibers from which defendant actually caused the disease is not always humanly possible.”); see id. at 368 (Lehrmann, J., dissenting) (citing plaintiffs' experts' testimony); see also Rutherford v. Owens-Illinois, 941 P.2d 1203, 1219 (1997) (citing “impossibility” of such proof); see generally Kiyoshi Sakai et al., Trends in Asbestos and Non-Asbestos Fibre Concentrations in the Lung Tissues of Japanese Patients with Mesothelioma, 58 AnNAls OCCUPATIONAL Hygiene 103, 103 (2014) (reporting millions of fibers per gram of dry lung in tissue of mesothelium patients occupationally exposed to asbestos).

54. Asbestos minerals may contain distinguishable types of fibers, e.g. chrysotile, amphibole, or tremolite, but one would not expect, say, the chrysotile in Georgia-Pacific joint compound to be distinguishable from the chrysotile in some other company's joint compound. I am aware of no case in which a defendant argued that physical or chemical fingerprinting could rule out its product as a cause of a particular mesothelioma.

55. See Bostic, 439 S.W.3d at 374-75 (Lehrmann, J., dissenting) (“[E]ven when a person's exposure exceeds background levels ... [f] ate must frown upon a person in more than one respect 
low levels of asbestos exposure-much smaller than the exposure required to produce asbestosis-increase the risk of mesothelioma. ${ }^{56}$ It is possible that asbestos exposure below some threshold level is incapable of inducing mesothelioma, but even if such a threshold exists, no one has yet been able to identify $i^{57}$ because, according to one of plaintiffs' experts, "that level is so low that we have not been able to measure it." ${ }^{, 58}$

The parties in Bostic agreed that the degree of risk is "dose-related" in the sense that the more asbestos a person is exposed to, the greater that person's risk of developing mesothelioma. ${ }^{59}$ Thus, incremental exposures that add to a

before he develops this rare form of cancer."); see also Thompson, supra note 10, at 4 ("only about $5 \%$ of those exposed to asbestos develop" malignant mesothelioma).

56. Bostic, 439 S.W.3d at 338 (contrasting levels of exposure needed to produce asbestosis and mesothelioma); id. at 367 (Lehrmann, J., dissenting) (describing testimony of plaintiffs' expert that research has identified a threshold level of exposure below which asbestos exposure does not cause asbestosis, but has demonstrated no such level for mesothelioma); see Georgia-Pacific Corp.'s Brief on the Merits at $30 \mathrm{n} .26$, supra note 50 (asserting, in the course of arguing that plaintiffs were required to and had failed to prove the minimum dose required for asbestos to cause mesothelioma, that the "minimum threshold of asbestos exposure that will lead to an increased risk of developing mesothelioma must, at a minimum, be higher than the background level of asbestos" in the air); see generally Xu et al., supra note 11, at 4388 ("Some individuals develop malignant mesothelioma following exposure to small amounts of asbestos, whereas others exposed to heavy amounts do not.").

57. See Bostic, 439 S.W.3d at 357-58 (describing and accepting arguendo plaintiffs' expert witnesses' testimony that scientists have identified no asbestos exposure threshold for mesothelioma causation).

58. Id. at 368 (Lehrmann, J., dissenting) (quotation marks and brackets omitted). In its briefs to the Supreme Court of Texas, Georgia-Pacific did not contest this description, despite arguing that plaintiffs could not prevail without establishing the threshold dose. Georgia-Pacific Corp.'s Brief on the Merits, supra note 50, at 2, 29-30.

59. See Bostic, 439 S.W.3d at 339 ("Plaintiffs' experts consistently testified that all asbestosrelated diseases are dose-related," and several relied on a report that stated "very low background environmental exposures carry only an extremely low risk"); Georgia-Pacific Corp.'s Brief on the Merits, supra note 50, at 4 n.4 ("Mesothelioma is a 'dose-response' disease, meaning that the risk of developing the disease increases as the level of exposure to asbestos increases.") (emphasis added); Petitioner's Brief on the Merits at 6, Bostic v. Georgia-Pacific Corp., 439 S.W.3d 332 (Tex. 2014) No. 10-0775 (citing proposed rule by the Consumer Product Safety Commission, introduced at trial, that stated that fibers from asbestos-containing joint compound "increase the risk of developing ... mesothelioma."). Higher exposure levels do not make mesothelioma more severe, however, unlike asbestosis. See Bostic, 439 S.W.3d at 338-39 (noting that asbestosis "appears to be dose-related, so that the more one is exposed, the more likely the disease is to occur, and the higher the exposure the more severe the disease is likely to be" while asbestos-caused mesothelioma is "dose-related" in that "the risk of developing" the disease "increased as the total occupational dose of inhaled asbestos fibers increased") (internal citations and quotation marks omitted); Michael D. Green, Second Thoughts About Apportionment in Asbestos Litigation, 37 Sw. U. L. REV. 531, 533-34 (2008). 
person's aggregate dose add incrementally to the person's risk. ${ }^{60}$ The Bostic plaintiffs and defendant disagreed fundamentally about the legal significance of this fact. ${ }^{61}$ But the defendant did not dispute that, at least above the presumed (but unidentified) threshold exposure level, additional asbestos exposures add to the risk of developing mesothelioma ${ }^{62}$ Nor did the defendant dispute that each exposure prior to reaching the threshold contributes to reaching it. ${ }^{63}$

This account of scientific knowledge of mesothelioma causation by asbestos does not comfortably fit traditional legal models of causation. The science suggests that multiple fibers, not necessarily inhaled at the same time and not necessarily contributed by the same source, may participate in the series of genetic changes necessary for "the" cellular transformation that eventually produces a fatal tumor. Each of these fibers, and therefore the act or product of each party that contributed one of them, would be a concurring but-for cause of the mesothelioma. But any of the asbestos fibers a person inhaled could have been among these "actual" causes. Therefore, all of the fibers (and their respective sources) could be viewed as competing causes. Discriminating among the competing causes to identify the "actual" concurring causes is impossible, but all of the different fibers from all of the different sources are concurrent contributors to the risk of developing mesothelioma.

Courts have tried various approaches to the disconnection between legal models of causation and a biological model of concurrent risk contribution. Bostic is the Supreme Court of Texas's effort. ${ }^{64}$ It failed spectacularly.

\section{Understanding Bostic's Misunderstandings of Cause-In-Fact}

Appealing the jury's verdict, Georgia-Pacific argued that "there is legally insufficient evidence that Georgia-Pacific asbestos-containing joint compound caused Timothy's mesothelioma." ${ }^{65}$ The Court of Appeals of Texas held that the plaintiffs had produced sufficient evidence to support a jury finding that Bostic was exposed to asbestos from Georgia-Pacific's joint compound, but insufficient proof that that exposure was a cause-in-fact of Bostic's disease and death. ${ }^{66}$

In its opinion, the court of appeals attempted to apply the Supreme Court of Texas's precedent in an asbestosis case, Borg-Warner Corp. v. Flores. ${ }^{67}$ The court understood Flores to require two components of proof to establish the

60. See generally Green, supra note 59, at 538-39 (describing risk contribution model in mesothelioma cases).

61. See Bostic, 439 S.W.3d at 337-39.

62. See id. (describing plaintiffs' evidence and argument without any suggestion that defendant adduced evidence contradicting that incremental exposures add incremental risk).

63. Id.

64. See id.

65. Georgia-Pacific Corp. v. Bostic, 320 S.W.3d 588, 591 (Tex. App. 2010), aff'd, 439 S.W.3d 332 (Tex. 2014) (footnote omitted).

66. Id. at 602 ("There is legally insufficient evidence of causation to support the verdict against Georgia-Pacific.”).

67. Borg-Warner Corp. v. Flores, 232 S.W.3d 765 (Tex. 2007). 
element of "causation in fact": a plaintiff must prove that but for exposure to defendant's asbestos product plaintiff would not have become ill and also that exposure to defendant's asbestos product was a substantial factor in producing plaintiff's disease. ${ }^{68}$ The court concluded that plaintiffs' proof failed on both scores, reversed the trial court judgment, and rendered judgment in favor of the defendant. ${ }^{69}$

First, the court of appeals noted that the plaintiffs' expert on specific causation declined to opine that Bostic would not have developed mesothelioma absent exposure to asbestos from Georgia-Pacific's products. ${ }^{70}$ Therefore, the court held the evidence of causation was insufficient "[b]ecause a plaintiff must prove that the defendant's conduct was a cause-in-fact of the harm." ${ }^{\prime 71}$

Second, the court of appeals decided that plaintiffs lacked both the qualitative and quantitative proof of exposure to defendant's asbestos-containing products that Flores required to support a substantial factor finding. ${ }^{72}$ Because "there is insufficient evidence of Timothy's frequent and regular exposure to Georgia-Pacific's asbestos-containing joint compound" "73 and the "evidence is insufficient to provide quantitative evidence of Timothy's exposure to asbestos fibers from Georgia-Pacific's asbestos-containing joint compound,"74 the court held that plaintiffs had not produced sufficient evidence to support a finding that Georgia-Pacific's products were a substantial factor in producing Bostic's disease. $^{75}$

The Supreme Court of Texas affirmed the court of appeals' judgment, speaking through an opinion written by Justice Don R. Willett and joined by five justices in all. ${ }^{76}$ The majority opinion stated that although the lower court was wrong to insist on proof of "but for" causation, it was right to require proof of "substantial factor" causation. ${ }^{77}$ The majority opinion then prescribed a detailed set of requirements for proof of substantial factor causation in multiple-exposure asbestos cases ${ }^{78}$ and finally held that the Bostic plaintiffs had not presented proof sufficient to satisfy these requirements. ${ }^{79}$ Justice Eva Guzman wrote a concurring opinion arguing that the majority's view of the substantial factor test was too

68. Georgia-Pacific, 320 S.W.3d at 596 ("“Common to both proximate and producing cause is causation in fact, including the requirement that the defendant's conduct or product be a substantial factor in bringing about the plaintiff's injuries."') (quoting Flores, 232 S.W.3d at 770 (quoting Union Pump Co. v. Allbritton, 898 S.W.2d 773, 775 (Tex. 1995))) (emphasis added).

69. Id. at 590 .

70. Id. at 596 .

71. Id.

72. Id. at 602 .

73. Id. at 599 .

74. Id. at 601 .

75. Id. at 602 .

76. Bostic v. Georgia-Pacific Corp. 439 S.W.3d 332, 336 (Tex. 2014).

77. Id. at 344 .

78. Id. at $346-50$.

79. Id. at 353-60. 
stringent but the dissent's too lax.$^{80}$ Three justices dissented in an opinion written by Justice Debra Lehrmann. ${ }^{81}$ The majority's decision is best understood by considering its components in the sequence described above, even though the court presented them in a different order.

\section{A. The Holding that Plaintiffs Need Not Prove "But For" Causation: At War With Itself}

All nine justices of the Supreme Court of Texas agreed that the plaintiffs "were not required to prove that but for Bostic's exposure to Georgia-Pacific's products, he would not have contracted mesothelioma." 82 The majority initially justified this conclusion on grounds of impossibility: "in multiple-exposure cases the plaintiff may find it impossible to show that he would not have become ill but for the exposure from that defendant." 83

The only possible quibble with the court's statement is with the word "may." The particular causative fibers cannot be identified and traced to a particular defendant; ${ }^{84}$ even if they could be, it still might not follow that but for exposure to those fibers the plaintiff would not have developed mesothelioma. ${ }^{85}$

The Supreme Court of Texas was hardly the first to recognize the impossibility of proof of but-for causation and the injustice of allowing that impossibility to preclude recovery in every multiple-exposure case. Many other courts wrestling with the same problem have found alternatives to the but-for test. ${ }^{86}$ The Bostic majority quoted the California Supreme Court's decision in a

80. Id. at 362 (Guzman, J. concurring).

81. Id. at 366 (Lehrmann, J., dissenting).

82. Id. at 346; see also id. at 361 (Guzman, J. concurring) (joining part II.A.2 of the majority opinion, which discussed "but for" causation); id. at 377-79 (Lehrmann, J. dissenting) (applying substantial factor test without reference to "but for").

83. Id. at 344; see also id. ("The long latency period for asbestos-related diseases, coupled with the inability to trace precisely which fibers caused disease and from whose product they emanated, make this process [of proving causation] inexact.”) (quoting Borg-Warner Corp. v. Flores, 232 S.W.3d 765, 772 (Tex. 2007)).

84. See text accompanying supra note 49.

85. See Steve C. Gold, When Certainty Dissolves Into Probability: A Legal Vision of Toxic Causation for the Post-Genomic Era, 70 WASH. \& LEE L. REv. 237, 288 \& n.211, 302 (2013) (discussing the possibility that even absent "the" causative fiber, the same or some other cell could have become malignant by action of other fibers).

86. See Sienkiewicz v. Greif, [2011] UKSC 10 [107-08], [2011] 2 WLR 523 (appeal taken from Eng.) (Lord Phillips) (stating that liability results from material contribution to the plaintiff's risk of mesothelioma); Rutherford v. Owens-Illinois, 941 P.2d 1203, 1220-21, 1223 (1997) (treating each exposure as a cause of disease because it contributed to risk); Lohrmann v. Pittsburgh Corning Corp., 728 F.2d 1156, 1163 (4th Cir. 1986) (adopting "frequency, regularity and proximity test" to distinguish causal from de minimis exposures); Ford Motor Co. v. Boomer, 736 S.E.2d 724, $732-33$ (Va. 2013) (holding that in lieu of but-for causation, multiple sources of asbestos exposure would be deemed causal provided each was sufficient to cause disease); Stapleton, supra note 41, 
case alleging asbestos-caused lung cancer:

[P]laintiffs may prove causation ... by demonstrating that the plaintiff's exposure to defendant's asbestos-containing product in reasonable medical probability was a substantial factor in contributing to the aggregate dose of asbestos . . . and hence to the risk of developing asbestos-related cancer, without the need to demonstrate that fibers from the defendant's particular product were the ones, or among the ones, that actually produced the malignant growth. ${ }^{87}$

The Bostic majority, however, did not adopt California's risk contribution model that it favorably quoted. Instead, Bostic took an end run around the stone wall of but-for causation-an end run that led down a dead-end street. The Bostic majority eliminated the requirement for proof of but-for causation, except that it didn't.

The retrenchment began immediately after the majority abjured but-for causation, when the majority chose to fight a battle no enemy had joined. The majority's nod to the realities of asbestos-induced mesothelioma carcinogenesis amply justified some alteration in the proof required to establish causation-infact; neither the concurrence nor the dissent questioned the substantial factor standard. Nevertheless, the majority went on to defend its use of the substantial factor formulation as consistent with the Restatements of Torts. ${ }^{88}$ That defense pulled the majority's train of reasoning far off the rails.

The majority observed that the but-for test "yields to the more general substantial factor causation in situations where proof of but for causation is not practically possible or such proof otherwise should not be required." ${ }^{89}$ On its face this formulation seems susceptible to the understanding that because it was "not practically possible" to determine which particular asbestos exposures were essential to the creation of Bostic's mesothelioma, courts should apply an alternative method for determining causation, such as a risk contribution model..$^{90}$

Instead of acknowledging the need to reconceptualize factual causation, the Bostic majority reached back to the earliest judicial uses of "substantial factor" that led to the phrase being enshrined in the Restatement of Torts in the first

at 191-93 (describing various uses of substantial factor causation in mesothelioma cases).

87. Bostic v. Georgia-Pacific Corp. 439 S.W.3d 332, 344 (Tex. 2014) (quoting Rutherford, 941 P.2d at 1219 (footnote omitted)).

88. Id. at 344-46.

89. Id. at 344.

90. See Rutherford, 941 P.2d at 1203, quoted in Bostic, 439 S.W.3d at 344-45. Rutherford may alternatively be viewed as re-conceptualizing the nature of the harm inflicted, from causing disease to causing a risk of disease. On this view, Rutherford would be perfectly consistent with the general rule requiring proof of but-for causation. See generally RESTATEMENT (THIRD) OF TORTS: Liab. FOR PhysicAl \& EMOTIONAL HARM $§ 26 \mathrm{cmt}$. f (2010) (noting, in comment on section defining a factual cause as a but-for cause, that sometimes "courts recognize new, unusual, or reconceptualized harms"); $i d$. $\S 26 \mathrm{cmt}$. $\mathrm{j}$ (noting that for policy reasons, when evidence is unavailable, courts may "permit recovery for unconventional types of harm”). 
place: the case of overdetermined outcomes. ${ }^{91}$ This situation is exemplified by the classic "two fires" case in which neither fire is literally a but-for cause of harm because absent either fire the harm would have resulted from the other; either fire was sufficient to bring about the result, so neither was necessary to do so. ${ }^{92}$

As the Bostic majority noted, the Restatement Third, like its predecessors, posits that each independently sufficient cause should be considered a cause-infact of the harm..$^{93}$ The majority called this an exception to the but-for rule in "cases of multiple causation" and concluded from it that "the Restatement Third, like the earlier Restatements, does not require strict but for causation in a toxic tort multiple-exposure case like today's case." ${ }^{.94}$ In leaping from risk contribution to multiple sufficient causes and equating multiple exposures with "multiple causation," the court silently switched from a model of contributing causes to a model of independently sufficient and possibly competing causes. ${ }^{95}$

The majority quoted comments $\mathrm{f}$ and $\mathrm{g}$ to section 27 of the Restatement Third. Comment $\mathrm{f}$ explains that the multiple sufficient cause rule can apply even if one actor's conduct must combine with another's to bring about the harm. ${ }^{96}$ Comment $g$ notes that this situation "has occurred most frequently in cases in

91. Bostic, 439 S.W.3d at 345 (citing Restatement (SECOND) of ToRTs § 432(2) (1966)); $i d$. at 346 (citing RestATEMENT (THIRD) OF TORTS: LiAB. FOR PHySiCAL \& EMOTIONAL HARM $§ 27$ cmt. a (2010)).

92. See Restatement (ThiRd) ofTorts: Liab. For PhysicAl \& Emotional Harm $\S 27 \mathrm{cmt}$. a (2010); Restatement (SECOND) OF TORTS § 432(2) (1966); Anderson v. Minneapolis, St. Paul \& Sault Ste. Marie Ry. Co., 179 N.W. 45, 49 (Minn. 1920); see also text accompanying supra note 45 (describing multiple sufficient cause model). This is the only use of "substantial factor" that the Restatement Third deems legitimate. Restatement (ThiRd) OF TORTs: Liab. FOR Physical \& EMOTIONAL HARM $\S 26 \mathrm{cmt}$. j (2010) ("With the sole exception of multiple sufficient causes, 'substantial factor' provides nothing of use in determining whether factual cause exists.").

93. Bostic, 439 S.W.3d at 346 (quoting RestATEMENT (ThiRd) OF TORTS: LiAB. FOR PhySiCAL \& EMOTIONAL HARM $§ 27$ (2010)).

94. Id. (emphasis added).

95. The majority accomplished this feat in the span of three sentences. The court noted that the Restatement Third presents but-for as the basic definition of factual causation. Id. ("Conduct is a factual cause of harm when the harm would not have occurred absent the conduct.") (quoting RESTATEMENT (THIRD) OFTORTS: Liab. FOR PhySICAL \& EMOTIONAL HARM $§ 26$ (2010)). But, the majority stated, the Restatement Third "does not require strict but for causation in a toxic tort multiple-exposure case like today's case" based on the exception for "cases of multiple causation." Id (emphasis added). $C f$. Restatement (ThiRd) of TORTs: Liab. FOR PhysicAl \& EMOtional HARM $\S 26 \mathrm{cmt}$. i (2010) (cautioning that courts must distinguish between multiple causes, competing causes, and multiple sufficient causes of harm).

96. Bostic, 439 S.W.3d at 346 (quoting Restatement (ThIRD) OF TORTS: LiAB. For PHYSICAL \& EMOTIONAL HARM $§ 27 \mathrm{cmt}$. $\mathrm{f}$ (2010) (stating that the section applies to cases in which "tortious conduct by one actor is insufficient ... to cause the plaintiff's harm" yet "when combined with conduct by other persons, the conduct overdetermines the harm" even though "an actor's conduct requires other conduct to be sufficient to cause another's harm")). 
which persons have been exposed to multiple doses of a toxic agent," ${ }^{, 97}$ which the court called "the scenario closest to our case": ${ }^{98}$ "a person contracts a disease such as cancer, and sues multiple actors claiming that each provided some dose of a toxic substance that caused the disease." "99 The comment assumes that a threshold dose exists that is sufficient to cause the disease and that the sick person was exposed to more than that threshold amount before getting sick. Because the threshold is exceeded, the disease is overdetermined and "some or all of the person's exposures may not have been but-for causes of the disease."100 "Nevertheless," applying the multiple-sufficient-cause rule, "each of the exposures prior to the person's contracting the disease ... is a factual cause of the person's disease."101

As the Supreme Court of Texas majority understood, comment g seems closely analogous to Bostic's case. ${ }^{102}$ The parties disagreed about whether exposure to a threshold dose of asbestos is required to cause mesothelioma, but even if the defendant was correct that a threshold exists, Bostic's mesothelioma is tautological proof that his exposure at least reached, and presumably exceeded, the threshold. Straightforward application of comment g would suggest that the exposure to Georgia-Pacific's asbestos-containing joint compound-along with every other pre-disease exposure-was a cause-in-fact of Bostic's mesothelioma. Yet the majority, despite quoting the comment, reached exactly the opposite conclusion. ${ }^{103}$

The unacknowledged shift in causal models mattered. The majority recognized the "complexities and what if scenarios" of the multiple sufficient cause rule, but failed to appreciate and apply the comments it quoted. ${ }^{104}$ Comments $f$ and $g$ treat every exposure as a necessary element of some sufficient causal set of exposures; per the comments the harm is overdetermined only because multiple such sets exist. ${ }^{105}$ But the Bostic majority focused on the relation among individually sufficient causal exposures. ${ }^{106}$ By relying on multiple sufficient causes to justify the abandonment of a but-for requirement, the Bostic majority eased its way into a causation analysis that effectively requires every defendant's contribution to a plaintiff's overall dose to be, by itself, sufficient to

97. Restatement (Third) of Torts: Liab. For Physical \& Emotional Harm $§ 27 \mathrm{cmt}$. $\mathrm{g}(2010)$.

98. Bostic, 439 S.W.3d at 346.

99. Restatement (Third) of Torts: Liab. For Physical \& Emotional Harm $§ 27 \mathrm{cmt}$. $\mathrm{g}(2010)$.

100. $I d$.

101. Id. (emphasis added).

102. Bostic, 439 S.W.3d at 346.

103. Id. at 360 .

104. Id. at 346.

105. Restatement (THIRD) OF TORTs: Liab. FOR PHysicAl \& EMOTIONAL HARM $§ 27 \mathrm{cmts}$. $\mathrm{f} \& \mathrm{~g}(2010)$.

106. See generally Bostic, 439 S.W.3d 332. 
cause disease.${ }^{107}$ Notwithstanding a plaintiff's obligation to "establish substantial factor causation," the majority insisted, "we hold that Plaintiffs . . . were not required to prove that but for Bostic's exposure to Georgia-Pacific's products, he would not have contracted mesothelioma." ${ }^{108}$ But then the majority proceeded to analyze the meaning of substantial factor in a way that, in essence, demanded exactly that.

\section{B. Holdings on the Meaning of Substantial Factor: Mixing, Not Matching, Causal Models}

Courts seeking an alternative to but-for causation in multiple-exposure cases have found that it takes considerable thought to explain how to distinguish substantial factors, insubstantial factors, and non-factors in causing a plaintiff's disease. ${ }^{109}$ The Bostic majority was no exception. But its thinking was fuzzy. In the end, the majority in Bostic not only imposed, but inappropriately stiffened, the but-for causation requirement it purported to relax.

To achieve this outcome, the Bostic majority implicitly invoked a different causal model at each stage of its analysis. The court applied a multiple sufficient cause model to establish a "more than risk-doubling" minimum level of exposure required to satisfy the substantial factor test, effectively requiring that the exposure attributable to each defendant be sufficient, in itself, to cause disease. ${ }^{110}$ The court applied a competing cause model to support its conclusion that small exposures could not be a cause-in-fact of mesothelioma. ${ }^{111}$ The court applied a concurring cause model, but one that mixed policy considerations with factual considerations, to support its holding that even some exposures that are independently sufficient to cause disease might not be considered a cause-infact. ${ }^{112}$

1. Requiring More than Doubling of Risk: Applying a Sufficient Cause Model to Concurring Causes.-The Bostic majority announced that the plaintiff in a multiple-exposure asbestos-mesothelioma case need not prove that fibers from a particular defendant's product were a but-for cause of the disease, but must prove that fibers from a particular defendant's product were a substantial factor in producing the disease ${ }^{113}$ What proof would satisfy the substantial factor test?

Taking a page from the risk contribution model, the Bostic majority equated

107. See infra Part III.B.1. The Supreme Court of Virginia did the same thing via a slightly different pathway. Ford Motor Co. v. Boomer, 736 S.E.2d 724 (Va. 2013). See infra note 135.

108. Bostic, 439 S.W.3d at 346.

109. See generally Sienkiewicz v. Greif, [2011] UKSC 10, [2011] 2 WLR 523 (appeal taken from Eng.); Rutherford v. Owens-Illinois, 941 P.2d 1203, 1220-21, 1223 (1997); Lohrmann v. Pittsburgh Corning Corp., 728 F.2d 1156, 1163 (4th Cir. 1986); Ford Motor Co., 736 S.E.2d at 732-33; Allen v. United States, 588 F. Supp. 247 (D. Utah 1984); Elam v. Alcolac, Inc., 765 S.W.2d 42 (Mo. Ct. App. 1988).

110. See Bostic, 439 S.W.3d at 350 (requiring doubling of risk).

111. See id. at 350-51 (requiring doubling of risk).

112. See id. at 351 (requiring doubling of risk).

113. Id. at 346 . 
substantiality of exposure with substantial factor causation. ${ }^{114}$ To show that an exposure was substantial, the Bostic majority held a plaintiff must quantify the dose of asbestos fibers received from a particular defendant's product or activity. ${ }^{115}$ After reviewing the evidence, the majority concluded that plaintiffs failed to introduce any quantitative proof of Bostic's exposure to asbestos from Georgia-Pacific's drywall mud. ${ }^{116}$

These holdings alone would have been adequate for the court to dispose of the case and render judgment for Georgia-Pacific. Justice Guzman, concurring, said as much ${ }^{117}$ However, Justice Willett and the four justices who fully joined his opinion chose to "write further on the meaning of substantial factor causation in asbestos cases." " They answered a question that, although incipient in their decision, was not essential to that decision: if a plaintiff did present satisfactory quantitative evidence of exposure to a particular defendant's asbestos-containing products, how much exposure would be enough to satisfy the "substantial factor" standard for causation-in-fact?

To answer this question the majority looked to the court's 1997 decision in Merrell Dow Pharmaceuticals, Inc. v. Havner. ${ }^{119}$ Adapting one of Havner's "insights that should be integrated with our analysis here," 120 the majority held that "to establish substantial factor causation in the absence of direct evidence of causation, the plaintiff must prove with scientifically reliable expert testimony that the plaintiff's exposure to the defendant's product more than doubled the plaintiff's risk of contracting the disease." "21

This holding is breathtakingly inconsistent with the theory of causation-infact of any sound tort doctrine. Once again shifting sub silentio to a paradigm of multiple sufficient causes, the majority, immediately after announcing that a plaintiff need not establish but-for causation, imposed an evidentiary requirement that most courts recognize as but-for causation's equivalent. Understanding this shift requires a basic understanding of Havner, its very different factual context, and its central holding that the Bostic majority borrowed.

Just as Bostic was one of many claims that relatively small asbestos exposures caused a plaintiff's mesothelioma, Havner was one of many claims that maternal ingestion of the anti-nausea drug Bendectin caused a plaintiff's

114. Id. at 349-51.

115. Id. at 353 (holding that "the dose must be quantified but need not be established with mathematical precision"). The majority explained that this "extend[ed] the reasoning of Flores" from asbestosis cases to mesothelioma cases. Id. at 342 .

116. $I d$. at $356,359-60$.

117. Id. at 364 (Guzman, J. concurring) (stating that plaintiffs, as a matter of law, needed to produce defendant-specific evidence of approximate dose and, as a matter of fact, failed to do so). The other rationale Justice Guzman presented in support of the result is discussed infra note 331 .

118. Id. at 346.

119. 953 S.W.2d 706 (Tex. 1997).

120. Bostic, 439 S.W.3d at 347.

121. Id. at 353 (emphasis added). 
birth defect. ${ }^{122}$ Causation-in-fact was the key issue in both cases, but the causal arguments were different. In Bostic there was no dispute that asbestos causes mesothelioma and no serious dispute that asbestos caused Bostic's mesothelioma; the question was which exposure(s), and therefore which defendant(s), caused the disease. ${ }^{123}$ In Havner, if Bendectin caused Kelly Havner to be born with missing fingers, it was indisputably Merrell Dow's Bendectin; ${ }^{124}$ the question was whether Bendectin caused birth defects at all, much less Havner's limb reduction specifically. ${ }^{125}$ Merrell Dow argued that the scientific basis for the plaintiffs' experts' causation opinions was unreliable and therefore the expert testimony did not constitute legal evidence of causation. ${ }^{126}$

"The Havners rel[ied] to a considerable extent on epidemiological studies" to prove that Bendectin caused birth defects. ${ }^{127}$ By definition, epidemiology studies groups of people rather than individuals, seeking (as pertinent here) to

122. See generally Gerald W. Boston, A Mass-Exposure Model of Toxic Causation: The Content of Scientific Proof and the Regulatory Experience, 18 COLUM. J. ENVTL. L. 181, 195-201 (1993) (describing the mass nature of asbestos and Bendectin exposures); Marc Galanter, Case Congregations and Their Careers, 24 L. \& SoC'Y REV. 371, 372 (1990) (describing common features of case congregations). Of course, the number of asbestos-mesothelioma claims dwarfs the number of Bendectin-birth defects claims. See JosePh SANDERS, BENDECTIN ON TRIAL: A STUdy OF MASS TORT LiTigation 43 (1998) (explaining that fifty to 100 claims were filed of a potential universe of 6,000 to 16,000); Sanders, supra note 11, at 1154 (stating that hundreds of thousands of asbestos claims have been filed). Among other reasons for the difference are: the vast difference in the quality of proof of agent-disease causation, the difference in the extent and duration of exposure and the number of cases of the alleged harm, and the difference in the availability of financially viable defendants. Id. at 1154-55 (describing factors accounting for longevity of asbestos litigation).

123. Bostic, 439 S.W.3d at 341.

124. See Michael D. Green, Bendectin and Birth Defects: The Challenges of Mass Toxic Substance Litigation 90 (1996) (describing development, approval, and marketing of Bendectin); SANDERS, supra note 122, at 214 (identifying various iterations of the Merrell corporation as "Bendectin's manufacturer").

125. Merrell Dow Pharm., Inc. v. Havner, 953 S.W.2d 706, 708-09 (Tex. 1997).

126. Merrell Dow argued both that plaintiffs' expert testimony should not have been admitted, id. at 709 (describing defendant's motion in limine to exclude plaintiffs' expert causation testimony), and that even if admissible, the testimony was too unreliable to support a factual finding of causation, $i d$. at 711 (describing defendant's motion for summary judgment). Under Texas law, the Daubert reliability/fit analysis determined admissibility of expert testimony. See E.I. du Pont de Nemours \& Co. v. Robinson, 923 S.W.2d 549, 556 (Tex. 1995) (holding that Texas Rule of Evidence 702 "requires the proponent to show that the expert's testimony is relevant to the issues in the case and is based upon a reliable foundation") (citing Daubert v. Merrell Dow Pharm., Inc., 509 U.S. 579 (1993)). On appeal of a jury verdict on grounds that the evidence was insufficient, Texas law specified a "no evidence" standard of review. Havner, 953 S.W.2d at 711 (describing circumstances under which court will determine that "there is no evidence of probative force to support a jury's finding").

127. Havner, 953 S.W.2d at 715. 
determine whether exposure to suspected toxins is associated with increased occurrence of diseases or conditions suspected to result from such exposure. ${ }^{128}$ Because many diseases of interest may occur either with or without exposure, and many exposures of interest may occur either with or without resulting disease, often epidemiology fundamentally measures risk: if an association exists and is deemed causal, ${ }^{129}$ epidemiologic studies yield one of several statistical measure ${ }^{130}$ that quantify, subject to the vagaries of sampling error, ${ }^{131}$ the extent to which exposure increases the risk of disease relative to the risk faced by unexposed people.

In Havner, the Supreme Court of Texas spent considerable energy grappling with the question of whether the relative risk found in such group-based studies could be used as proof of causation in an individual case. ${ }^{132}$ The court framed the issue as follows:

General causation is whether a substance is capable of causing a particular injury or condition in the general population, while specific

128. See Gary H. Spivey, The Epidemiological Method, in ENVIRONMENTAL EPIDEMIOLOGY 9, 14-16 (William M. Draper ed., 1994).

129. The mere existence of an association does not necessarily mean that the observed increase in risk is causal. Epidemiologists typically apply their judgment to a suite of considerations to support an inference of causation from an observed association. See Austin Bradford Hill, The Environment and Disease: Association or Causation?, 58 Proc. RoYALSOC'Y OFMED. 295 (1965). For purposes of this article's discussion of the legal role of epidemiologic relative risk that is prescribed by Bostic, I assume that the observed increases in relative risk are causal.

130. Epidemiologic results may be reported as any of several values depending on a study's design. For example, in a cohort study, the incidence of disease among an exposed sample is compared to the incidence of disease among an unexposed sample and reported as "relative risk." In a case-control study, the likelihood that a sick person was exposed is compared to the likelihood that a healthy person was exposed and reported as "odds ratio." Epidemiologic results may also be reported as attributable risk or attributable fraction, standardized incidence ratio, or (if the studied outcome is death) standardized mortality ratio. Conceptually, these measures all describe the same thing. See Green et al., supra note 3, at 348-52 (describing relative risk, odds ratio, and attributable risk); MaryFran Sowers, Design Methods for Occupational and Environmental Epidemiology, in ENVIRONMENTAL EPIDEMIOLOGY, supra note 128, at 21, 25 (explaining that odds ratio "is considered a surrogate estimate of the relative risk.").

131. Statistical theory holds that any study measuring a characteristic (such as relative risk) in a sample of a population can only approximate the value of the measurement for the population as a whole. Thus, although relative risk is reported as a single calculated value, it is always subject to sampling error and unlikely to be replicated exactly in a subsequent study. See ROBERT R. SOKAL \& F. JAMES RohlF, Biometry 158 (4th ed. 2012) (describing confidence intervals). The risk of sampling error is unavoidable and is conventionally addressed by statistical techniques that estimate the likelihood of incorrectly finding an association by random chance (Type I error). See Green et al., supra note 3, at 575-78. Epidemiologic research is also potentially subject to other sources of error that can sometimes be addressed by careful study design but cannot be subjected to statistical testing. See id. at 583-97.

132. Havner, 953 S.W.2d at 714-15. 
causation is whether a substance caused a particular individual's injury. In some cases, controlled scientific experiments can be carried out to determine if a substance is capable of causing a particular injury or condition, and there will be objective criteria by which it can be determined with reasonable certainty that a particular individual's injury was caused by exposure to a given substance. However, in many toxic tort cases, direct experimentation cannot be done, and there will be no reliable evidence of specific causation.

In the absence of direct, scientifically reliable proof of causation, claimants may attempt to demonstrate that exposure to the substance at issue increases the risk of their particular injury. The finder of fact is asked to infer that because the risk is demonstrably greater in the general population due to exposure to the substance, the claimant's injury was more likely than not caused by that substance. Such a theory concedes that science cannot tell us what caused a particular plaintiff's injury. It is based on a policy determination that when the incidence of a disease or injury is sufficiently elevated due to exposure to a substance, someone who was exposed to that substance and exhibits the disease or injury can raise a fact question on causation. ${ }^{133}$

Despite some uneasiness with the policy determination, the Havner court nevertheless concluded that the impossibility of "direct" proof of causation justified allowing plaintiffs to rely on "scientifically reliable epidemiological studies." ${ }^{34}$ The court set strict methodologic standards for scientific reliability ${ }^{135}$ and also decided how much additional risk would be "sufficiently elevated" to "raise a fact question on causation." 136 The court held that the epidemiologic data must show that the studied exposure more than doubled the risk of a plaintiff's disease or condition. ${ }^{137}$ There is, the court concluded, "a rational basis for

133. Id.

134. Id. at 718 ("We recognize ... that frequency data, such as the incidence of adverse effects in the general population when exposed, cannot indicate the actual cause of a given individual's disease or condition. But the law must balance the need to compensate those who have been injured by the wrongful actions of another with the concept deeply imbedded in our jurisprudence that a defendant cannot be found liable for an injury unless the preponderance of the evidence supports cause in fact.") (citations omitted).

135. The court imposed standards of statistical significance, replication, and similarity of the plaintiff to the study subjects that must be satisfied for an epidemiologic study or an expert's causal inference to be deemed "reliable." See generally id. at 721-25 (statistical significance); id. at 727 (replication); id. at 720-21 (similarity); see also Merck \& Co. v. Garza, 347 S.W.3d 256, 265-66 (Tex. 2011) (emphasizing that these requirements must be strictly observed).

136. Havner, 953 S.W.2d at 715.

137. See id. at 717-18 (adopting "more than doubling of risk" standard despite arguments that the standard is either too stringent or too lenient); $i d$. at 725 (noting, in the course of rejecting plaintiffs' experts' reliance on certain studies, that 'the relative risk would need to exceed 2.0, and 
relating the requirement that there be more than a 'doubling of the risk' to our no evidence standard of review and to the more likely than not burden of proof."138 This "doubling-plus" rule neatly disposed of Havner, as the plaintiffs presented no epidemiologic data that satisfied both the court's methodologic requirements and the court's doubling-plus requirement. ${ }^{139}$

Havner did not even hint at how the doubling-plus rule should apply if more than one defendant or source were responsible for exposing a plaintiff to separate doses of the same toxic substance. ${ }^{140}$ The Bostic majority, however, borrowed the doubling-plus rule from Havner and applied it to the multiple-exposure context with a brisk elision of the legal issues in the two cases:

Havner enunciated principles in toxic tort cases that . . . where direct evidence of causation is lacking, scientifically reliable evidence in the form of epidemiological studies showing that the defendant's product more than doubled the plaintiff's risk of injury appropriately corresponds to the legal standard of proof by a preponderance of the evidence. These principles should apply to asbestos cases .... We therefore conclude that in the absence of direct proof of causation, establishing causation in fact against a defendant in an asbestos-related disease case requires scientifically reliable proof that the plaintiff's exposure to the defendant's product more than doubled his risk of contracting the disease. A more than doubling of the risk must be shown through reliable expert testimony that is based on epidemiological studies or similarly reliable scientific testimony. ${ }^{141}$

Of course, in Havner "the defendant's product" meant Bendectin generally; in Bostic "the defendant's product" meant the quantity of asbestos from GeorgiaPacific's joint compound to which Bostic was exposed while his father did home renovation projects. ${ }^{142}$

The dissenting justices in Bostic complained that " $[\mathrm{t}]$ he framework we approved in Havner ... did not contemplate a factual scenario involving multiple

the confidence interval could not include 1.0, for the results to indicate more than a doubling of the risk and a statistically significant association between Bendectin and limb reduction birth defects" and that a relative risk possibly as great as 1.8 "is not a doubling of the risk" and could not establish causation even if it could support an "opinion that it is more probable than not that there is an association between Bendectin and limb reduction defects") (emphasis added).

138. Id. at 717 .

139. Id. at 724-28 (describing plaintiffs' experts' testimony on epidemiology).

140. See Bostic v. Georgia-Pacific Corp., 439 S.W.3d 332, 371 (Tex. 2014) (Lehrmann, J. dissenting) ("Havner did not address ... whether, when multiple sources contribute to a plaintiff's exposure, the plaintiff's exposure to the defendant's product was a substantial factor in causing his injury. This stands to reason because, in that case, the plaintiff had only been exposed to Bendectin from one source.").

141. Id. at 349-50 (emphasis added).

142. Id. at 337. 
manufacturers."143 The majority responded dismissively: "We are at a loss to understand why[]" Havner would not apply to multiple-exposure cases. ${ }^{144}$ The explanation lies in the rationale for Havner's doubling-plus rule, which the majority failed to consider. Consequently, the Bostic majority switched to an inapposite causal model either without noticing or without admitting that it was doing so.

The central justification for the doubling-plus rule, in Havner and elsewhere, is that if an exposure more than doubles the risk of a disease, then it is more likely than not that the exposure caused any given case of the disease in a person who suffered that exposure. ${ }^{145}$ As described above, epidemiologists compare the estimated incidence of a disease among the unexposed population to the estimated incidence of the disease in the exposed population, assuming that absent the effects of exposure, the two incidence rates would be equal. If researchers find an increased incidence of disease among exposed individuals and satisfy themselves that the result is neither a statistical sampling fluke nor a mere coincidence, they will attribute to the exposure the excess cases above the level observed in the unexposed sample. The fraction of disease attributable to exposure follows directly from the amount of increased risk. If the relative risk is two, then two cases were observed among the exposed where one would have been expected absent exposure; the attributable fraction is one out of two or fifty percent. ${ }^{146}$ Any relative risk above two implies that more than half of the cases of disease in the exposed population are attributable to the exposure, in which case, if a sick person is chosen at random from among the exposed, the probability is greater than fifty percent that the randomly selected case will be one that can be attributed to the exposure. ${ }^{147}$

Courts conventionally express the preponderance of the evidence standard as proof that causation (or any other fact) is "more likely than not" true. ${ }^{148}$ The doubling-plus rule depends on equating the population-based probability derived by epidemiology with the individual-case probability demanded by law. ${ }^{149}$ This is how doubling-plus supposedly "corresponds," in Bostic's term, to the

143. Id. at 371 (Lehrmann, J. dissenting).

144. Id. at 352 .

145. Merrell Dow Pharm., Inc. v. Havner, 953 S.W.2d 706, 717 (Tex. 1997); see also In re “Agent Orange" Prod. Liab. Litig., 597 F. Supp. 740 (E.D.N.Y. 1984), aff'd, 818 F.2d 145 (2d Cir. 1987); Cook v. United States, 545 F. Supp. 306 (N.D. Cal. 1982); Estate of George v. Vt. League of Cities \& Towns, 993 A.2d 367 (Vt. 2010). For a canvass of decisions to early 1999 that discuss the doubling-plus rule, see Russelyn Carruth \& Bernard Goldstein, Relative Risk Greater than Two in Proof of Causation in Toxic Tort Litigation, 41 JURIMETRICS J. 195 (2001).

146. See supra notes $128-31$ and accompanying text.

147. Treating relative risk as a single fixed value is an oversimplification. See supra note 131.

148. See, e.g., Restatement (ThiRd) OF ToRTs: Liab. FOR PhysicAl \& EMOtional HaRm § $26 \mathrm{cmt} .1$ (2010).

149. See Merrell Dow Pharm., Inc. v. Havner, 953 S.W.2d 706, 717 (Tex. 1997) (stating that if the relative risk is greater than two "it may be statistically more likely than not that a given individual's disease was caused by the drug"). 
preponderance of the evidence standard. ${ }^{150}$ Many commentators (myself included) have criticized this reasoning, ${ }^{151}$ but even if it is accepted for discussion purposes, the Bostic majority's use of doubling-plus logic cannot withstand scrutiny.

But-for causation inheres in the logic of the doubling-plus rule. The legal model, rooted in the epidemiologic concept of attributable fraction, implies that each case of disease is either "really caused" by the exposure or "really caused" by something else, and that the relative risk tells the factfinder which is more likely. To say that a relative risk not greater than two leads to the conclusion that something else caused a particular plaintiff's illness is no different from saying that it is as likely or more likely than not that the plaintiff's disease would have occurred even without the exposure. Conversely, to say that a relative risk greater than two leads to the conclusion that the exposure caused a particular plaintiff's illness is no different from saying that it is more likely than not that the plaintiff would not have been sick had she or he not been exposed. The doubling-plus rule does not replace but-for causation with a substantial factor, contributing factor, or risk contribution concept; it simply creates an epidemiologic threshold for determining whether but-for causation exists.

Havner itself made this evident. The Havner court pointed out that "some limb reduction defects are genetic[]" and "the cause of a large percentage of limb reduction birth defects is unknown[,]" raising the question "what must a plaintiff establish to raise a fact issue on whether Bendectin caused an individual's birth defect?" ${ }^{52}$ The very framing of the issue set up the possible causes-Bendectin or something else-as competing. The phrase "substantial factor" never even appeared in the Havner opinion. ${ }^{153}$

The same logic could apply if the relative risk were to vary with the amount of exposure. Were information about different relative risks at different exposure levels available, a court applying the doubling-plus rule would divide the world into three categories: unexposed (no proof of causation because no proof of

150. Bostic v. Georgia-Pacific Corp., 439 S.W.3d 332, 349 (Tex. 2014).

151. See, e.g., Sander Greenland \& James M. Robins, Epidemiology, Justice, and the Probability of Causation, 40 JURIMETRICS J. 321, 322 (2000) (noting that "equating the probability of causation to the attributable fraction leads to systematic underestimation" of probability of causation); Bernard D. Goldstein, Toxic Torts: The Devil Is in the Dose, 16 J.L. \& PoL'Y 551, 57177 (2008) (criticizing Havner's doubling-plus rule). Havner itself cited numerous critics of doubling-plus. See Havner, 953 S.W.2d at 716-17; see generally RESTATEMENT (THIRD) OF TORTS: LIAB. FOR PHYSICAL \& EMOTIONAL HARM $§ 28 \mathrm{cmt}$ c. reporters' note (2010) (citing court opinions and scholarly literature discussing doubling-plus rule).

152. Havner, 953 S.W.2d at 714.

153. Havner also did not mention "but for" causation, but the court had no need to articulate the traditional conception of causation that the court so clearly employed. Havner's sole reference to risk factors, other than within citations, described the epidemiologic concept of "attributable proportion of risk" as "the "proportion of the disease among exposed individuals that is associated with the exposure."” Id. at 721 (quoting Linda A. Bailey et al., Reference Guide on Epidemiology, in Federal Judicial Center, Reference Manual on Scientific Evidence 169, 149 (1994)). 
exposure), exposed to a dose no greater than the dose required to double the risk (insufficient evidence for a jury to find that exposure more likely than not caused the plaintiff's disease), and exposed to a dose greater than the doubling dose (sufficient evidence of factual causation to reach a jury). ${ }^{154}$ Regardless of the number of exposure categories, the doubling-plus rule still equates proof of relative risk greater than two with proof that but-for causation is more likely than not. Thus, when the Bostic majority concluded that "Havner's focus on proof of more than a doubling of risk ... is premised on fundamental principles of tort law that have application here," the fundamental principles to which it referred included the but-for causation standard that the majority had rejected a few paragraphs earlier-despite the majority's characterization of doubling-plus as requisite for a plaintiff "to establish substantial factor causation." 155

The problems with Bostic's use of Havner, however, go far beyond inconsistency. In the name of defending fundamental principles of tort law, Bostic actually did violence to elementary principles of causation-in-fact.

The reasoning of the Bostic majority works out to something like this: in a multiple-exposure mesothelioma case, the competing cause model is inappropriate because science cannot tell which fibers from which defendant(s) actually caused the cellular alterations without which the disease would not have developed. Therefore, a plaintiff need not prove that a defendant's exposure was a but-for cause of mesothelioma. Science can say that individual exposures contributed to risk, however, which fits a contributing or concurring cause model. Therefore, a plaintiff must prove substantial factor causation as to each defendant. To prove substantial factor causation, a plaintiff must satisfy a rule derived from a competing cause model by proving that the exposure contributed by each defendant individually more than doubled the plaintiff's risk. ${ }^{156}$ Per the doubling-plus rule, such a showing is tantamount to proving that a defendant more likely than not was a but-for cause of the harm. Tautologically, a but-for cause was both necessary and independently sufficient (together with the

154. Havner to some extent foreshadowed the possibility that a plaintiff might be able to prove some exposure, but not enough exposure to have doubled the risk. See id. at 720 (stating that plaintiffs who could produce studies showing more than a doubling of risk must prove that they received a dose at least equal to the dose of the exposed study subjects). However, Havner did not in any way consider how the doubling-plus rule might apply in multiple-exposure contexts.

155. Bostic v. Georgia-Pacific Corp., 439 S.W.3d 332, 348, 353 (Tex. 2014) (emphasis added).

156. The Bostic majority held that plaintiffs' case failed because the plaintiffs' "experts did not show, through reliance on scientifically reliable evidence, that Bostic's exposure to asbestos from Georgia-Pacific's products more than doubled his risk of contracting mesothelioma." Id. at 359; see also id. at 353 (holding that "the plaintiff must prove with scientifically reliable expert testimony that the plaintiff's exposure to the defendant's product more than doubled the plaintiff's risk of contracting the disease.") (emphasis added). The majority made clear that this requirement entails quantitative proof of the amount of exposure that resulted from use of each defendant's product and epidemiologic proof that that much exposure more than doubled the risk. See id. at $353,356,358$. 
universe of background causes in the causal set) to bring about the harm. Thus the Bostic majority invented a new sufficient-cause requirement: for a defendant's product to be a substantial factor in bringing about the plaintiff's harm, that product must independently be a sufficient cause, by itself, of plaintiff' s harm. ${ }^{157}$ Conversely, according to Bostic, only sufficient causes can be substantial factors. ${ }^{158}$

This result is inconsistent with elementary causation principles. Bostic's various exposures to asbestos were concurring causes of an elevated risk of mesothelioma that was a function of his aggregate exposure, not a set of separate functions of discrete exposures from separate contributors. The Bostic majority's rule illogically implies that several defendants could tortiously contribute to an exposure that was cumulatively sufficient to cause mesothelioma (i.e., that more than doubled the risk) but none would be a cause-in-fact-even if each and every separate dose was a necessary element of the set of doubling-dose exposures.

Imagine a poison that causes no harm at all at doses less than 100 units, but

157. Id. at 373 (Lehrmann, J., dissenting). Even under the majority's sufficient cause model, if more than one exposure exceeded the doubling dose, all could be considered substantial factors; as the majority recognized, multiple sufficient causes are the classic example of substantial factor causation. But under the majority's reasoning, if two or more exposures-each insufficient on its own - combined to bring about the plaintiff's disease, none could be a substantial factor.

158. Remarkably, the Bostic majority was not the first court to issue a holding with such an effect. In Ford Motor Co. v. Boomer, 736 S.E.2d 724 (Va. 2013), the Supreme Court of Virginia considered a claim that a state trooper's mesothelioma was caused by asbestos fibers from Ford brakes to which he was exposed (along with fibers from other brands of brakes) during vehicle inspections. The court noted the difficulty, "in the context of a lifetime of potential asbestos exposures, [of] designating particular exposures as causative." Id. at 729. The court recognized that "if the traditional but-for definition of proximate cause was invoked, the injured party would virtually never be able to recover for damages arising from mesothelioma in the context of multiple exposures." $I d$. The trial court, recognizing the same thing, had instructed the jury to find causationin-fact if it found a defendant's product was a "substantial contributing factor in causing plaintiff's injury." Id. at 153 (emphasis in original). The Supreme Court of Virginia rejected this instruction, following - and perhaps misreading — the Restatement Third's renunciation of "substantial factor." Id. The court noted that the Restatement Third asserted that the case of multiple sufficient causes was the only one in which substantial factor had utility as a substitute for strict but-for causation. Id. at 731. The court then reasoned that because but-for causation was impossible to prove in multiple-exposure mesothelioma cases, but-for should be replaced by the only available option: a rule that the asbestos exposure from a defendant's product, even if not a but-for cause, would be treated as a cause-in-fact if and only if the "exposure [was] sufficient to cause harm that occurred prior to the development of the cancer[, which] may constitute one of multiple sufficient causes under the Restatement and a concurring cause in Virginia." Id. at 732. Thus, Boomer, which seemed simply to misunderstand the Restatement Third, made the same mistake as Bostic-requiring every concurring cause to be a sufficient cause rather than recognizing the possibility that individually insufficient causes may combine to create harm. But Boomer was more open and honest about this requirement than is Bostic, which shrouded the holding in hidden changes of causal models and court-created rules of epidemiologic proof. 
is invariably lethal at doses of 100 units or more. If each of ten parties exposes a person to ten units of the poison, the act of every one of them is a cause-infact - a but-for cause — of the person's death, even though no party contributed a dose sufficient to cause any disease. For that matter, if one party exposes a person to ninety-nine units and a second party exposes the person to one unit, the acts of both parties-even the one-unit contributor-are but-for causes of the death. ${ }^{159}$

Now suppose that instead of a sharp threshold between exposures that never or always cause disease, the risk of disease gradually increases with the amount of exposure, such that a dose of 100 confers just more than double the risk of disease as compared to a dose of zero in unexposed people. As doses increase above 100, the relative risk increases, but always exceeds two. Doses smaller than 100 increase the risk, but by less than a factor of two. ${ }^{160}$ Assume that a plaintiff is exposed to 100 units of the substance. Because the relative risk of the plaintiff's exposure exceeded two, under the doubling-plus rule the plaintiff would have sufficient evidence to prove that it is more likely than not that the exposure (as opposed to other possible causes that produce the "background" incidence of disease) caused plaintiff's illness. If one defendant were tortiously responsible for the entire exposure, that defendant's tort would be a cause-in-fact of plaintiff's disease.

But what if plaintiff had been exposed to two doses of fifty units each by two tortfeasors acting independently? Once again, under the doubling-plus rule it is more likely than not that exposure to the substance caused plaintiff's disease because the doubling dose threshold was exceeded. Each defendant's tort is a but-for cause of that exceedance. That is, but for either defendant's tortious act, the plaintiff would have been exposed to only fifty units of the substance, making it less likely than not that the plaintiff's illness resulted from exposure to the substance. Thus each defendant provided a dose that made it more likely than not that the plaintiff's disease resulted from exposure to the substance (as opposed to being a "background" case). Yet under Bostic neither defendant's tort would be a substantial factor in bringing about the disease and neither defendant's tort would be a cause-in-fact.

Next, what if plaintiff had been exposed to three doses of ninety-nine units each by three tortfeasors acting independently? For the sake of the hypothetical, assume further that the dose-response curve is linear, so the plaintiff's cumulative exposure of 297 units confers a relative risk very close to six. Applying the logic of the doubling-plus rule, one would infer that it is very likely that exposure to

159. See Restatement (ThiRd) OfTorts: Liab. FOR Physical \& Emotional Harm $\S 36 \mathrm{cmt}$. b (2010) (noting that in the absence of overdetermined causation, "the actor who negligently provides the straw that breaks the camel's back is subject to liability for the broken back").

160. So long as the relationship between dose and response is monotonic-that is, so long as any given dose always confers at least as much risk as smaller doses- the exact shape of the doseresponse curve for disease risk is unimportant to the example. It might be linear, logarithmic, exponential, logistic - no matter. As will be seen, the analysis also remains the same regardless of whether there is a threshold dose below which disease risk is not increased at all. 
the substance caused plaintiff's disease. ${ }^{161}$ Yet the Bostic majority's holding would compel the conclusion that none of the defendants caused the illness.

In the immediately preceding example, the doubling of risk is overdetermined. No single exposure doubled plaintiff's risk. No single exposure was a but-for cause of the more than doubling of risk because absent any one, the other two would still have more than doubled the risk. But each exposure was a necessary element of a sufficient set of two exposures that, together, more than doubled-nearly quadrupled - the risk, even without the third exposure. As the Bostic dissenters noted, this hypothetical closely parallels the illustration of multiple sufficient causal sets from the Restatement Third. ${ }^{162}$ The illustration explains the Restatement's comment that where multiple sufficient causal sets exist, every necessary element of each of the sufficient causal sets is a factual cause of the harm. The Bostic majority quoted the Restatement comment but ignored its teaching, holding instead that none of the elements is a factual cause.

Finally, return to the hypothetical plaintiff who received ten exposures of ten units each by the tortious acts of ten different defendants acting independently. The doubling-plus rule again posits that exposure to the substance more likely than not caused the plaintiff's illness. And again, each exposure is a but-for cause of the more than doubling of risk because absent any one of them, the plaintiff would not have been exposed to a dose greater than the doubling threshold.

This is true even if each ten-unit exposure is below the "no effect" threshold for the substance. In this scenario, no defendant's act, alone, caused any increased risk at all. But combined with the other defendants' acts, each caused more than a doubling of risk and, under the doubling-plus rule, would be a factual cause of the harm. The Bostic majority's holding, however, once again would compel the conclusion that none of these exposures caused the plaintiff's harm.

In the sub-threshold hypothetical, each ten-unit exposure is analogous to a driver who speeds through a four-way stop past a pedestrian standing on the sidewalk at the corner. The driver is negligent but causes no harm to the pedestrian. Another driver might run the stop sign on the crossing street, still with no harm done. But if the two drivers happen to run the stop sign at the same time, causing a collision in which the pedestrian is injured by one of the ricocheting vehicles, each driver's negligence is a factual cause of the pedestrian's harm-even though each driver's conduct, independently, was insufficient to cause any harm to the pedestrian at all. ${ }^{163}$

If the doubling-plus rule of Havner is taken seriously-and the Bostic majority unquestionably took Havner seriously - then proof of an exposure that

161. In a population exposed to a dose with a relative risk of six, five of every six cases $(83.3 \%)$ would be attributed to exposure.

162. Bostic v. Georgia-Pacific Corp., 439 S.W.3d 332, 373-74 (Tex. 2014) (Lehrmann, J., dissenting) (quoting Restatement (THIRD) OF TORTS: LIAB. FOR PHYSICAL \& EMOTIONAL HARM $\S 27 \mathrm{cmt}$. f, illus. b (2010)).

163. I thank Michael Green for reminding me of this analogous hypothetical. See MARC A. Franklin ET AL., TORT LAW AND Alternatives 364 (9th ed. 2011). 
more than doubles a plaintiff's risk is equivalent to proof by a preponderance of the evidence that exposure to the substance was necessary and sufficient to cause the plaintiff's disease. Yet, if multiple sources of exposure must combine to exceed the risk-doubling threshold, the Bostic majority effectively held that none of those sources is a cause-in-fact. This holding contradicts basic tort principles and the Restatement on which the majority purported to rely; as the dissenters stated, it "does not just offend logic_-it offends justice." 164

2. Rejecting "Any Exposure": Applying a Competing Cause Model to Risk Contribution.-The Bostic plaintiffs argued against applying the doubling-plus rule to Georgia-Pacific's individual contribution to Bostic's asbestos exposure. ${ }^{165}$ Instead, they argued that they had proven that Bostic's exposure to asbestos from Georgia-Pacific's drywall mud was sufficient to be a substantial factor in causing Bostic's mesothelioma. ${ }^{166}$ The court's majority disagreed, holding that plaintiffs had failed to establish the extent of Bostic's exposure to Georgia-Pacific asbestos fibers. ${ }^{167}$ From that conclusion and the plaintiffs' experts' testimony that all exposures above background contributed to an elevated risk of mesothelioma, ${ }^{168}$ the majority inferred that plaintiffs could prevail only if "every," "any," or "some" exposure to asbestos from defendant's product was proven to be a causein-fact of Bostic's disease. ${ }^{169}$ The majority then held that such testimony could never be sufficient to establish factual causation. ${ }^{170}$

To explain that holding, the majority began with the observation that even "small amounts" of asbestos can cause mesothelioma. ${ }^{171}$ This seems incongruous: if a small amount of asbestos can cause mesothelioma, why couldn't the plaintiffs

164. Bostic, 439 S.W.3d at 374 (Lehrmann, J., dissenting).

165. See Petitioner's Brief on the Merits, supra note 59, at 32-33 (contrasting individually sufficient more-than-risk-doubling exposures with substantial contributing exposures).

166. Id. at 16-19; see Bostic, 439 S.W.3d at 375 (Lehrmann, J., dissenting).

167. Bostic, 439 S.W.3d at 338 (Flores required quantification of dose); id. (mesothelioma should be same as asbestosis); id. at 353 (plaintiff must establish and quantify the dose received from each defendant's product, though not with mathematical precision); id. at 353-54 (highlighting heuristic uncertainties in Bostic's dose from Georgia-Pacific products); id. at 355 ("Plaintiffs did not establish even an approximate dose.").

168. See id. at 356 ("Rather than attempting to quantify the aggregate dose of asbestos attributable to Georgia-Pacific's products, plaintiffs' experts expressly eschewed this approach in favor of the view that any exposure at all was sufficient to constitute a cause of the disease ....'); $i d$. at 338-39 (rejecting invitation to distinguish mesothelioma cases from asbestosis cases although "relatively minute quantities of asbestos can result in mesothelioma" while "development of asbestosis requires a heavy exposure").

169. Id. at 338 (holding that "even in mesothelioma cases proof of 'some exposure' or 'any exposure' alone will not suffice to establish causation," even though "small amounts of asbestos exposure can result in mesothelioma"); $i d$. at 354-55 (noting that plaintiffs' experts "repeatedly testified that 'each and every exposure' to asbestos was a cause of Bostic's disease" and holding this evidence legally insufficient).

170. Id. at 355.

171. Id. at 338. 
prove that a small exposure to asbestos from Georgia-Pacific's joint compound was a cause of Bostic's mesothelioma? The problem, according to the majority, is not that the defendant's product could not have caused the disease, but that the "any exposure" theory implies that other exposures might have caused it. ${ }^{172}$ After all, "everyone is exposed to asbestos in the ambient air,"

We fail to see how the theory can, as a matter of logic, exclude higher than normal background levels as the cause of the plaintiff's disease, but accept that any exposure from an individual defendant, no matter how small, should be accepted as a cause in fact of the disease. ${ }^{174}$

The majority complained that "[a]cceptance of an any exposure theory would . . . impose liability even where, for all the jury can tell, the plaintiff might have become ill from his exposure to background levels of asbestos or for some other reason." 175

The above quotations make sense only if the causal possibilities are competing. The majority implicitly assumed that Bostic's mesothelioma was caused by asbestos in Georgia-Pacific's drywall mud, or by background levels of asbestos, or by "some other" cause, ${ }^{176}$ but not by more than one of them acting independently or by any combination of them acting together. The majority's analysis is indistinguishable from decisions in other toxic tort cases that applied a competing cause, but-for model of causation by asking, for example, whether radiation from uranium mining and milling as opposed to other factors caused plaintiffs' cancers or thyroid disease. ${ }^{177}$

172. Id. at 339 .

173. Id. (quoting Flores v. Borg-Warner Corp., 232 S.W.3d 765, 767 (Tex. 2007)).

174. Id. at 341. It is worth noting that even if "higher than normal background levels" of asbestos are found in some places and are associated with elevated risks of mesothelioma, the court did not say that any evidence in the Bostic record suggested that Bostic may have experienced unusually great background exposure. The Bostic majority left unclear whether plaintiffs bear an obligation to prove the extent of their background exposure to establish specific causation.

175. Id. at 339 .

176. The majority did not make clear what "some other reason" might have been the real cause of Bostic's mesothelioma. As there was no real dispute that asbestos caused his disease, presumably the potential "other reason[s]" would be other exposures to asbestos.

177. See Wilcox v. Homestake Mining Co., 619 F.3d 1165 (10th Cir. 2010) (holding that under New Mexico law, substantial factor causation did not apply to plaintiffs' claims, which failed because plaintiffs' evidence was insufficient to establish but-for causation); June v. Union Carbide Corp., 577 F.3d 1234 (10th Cir. 2009) (holding that under Colorado law, plaintiffs' expert testimony opining that each plaintiff's radiation dose from mine tailings was a substantial factor in causing disease was legally insufficient for failing to state that plaintiffs' illnesses would not have occurred but for the tailings exposure). For comparable examples involving other toxic exposures, see, e.g., Baker v. Chevron USA, Inc., 680 F. Supp. 2d 865, 878 n.9 (S.D. Ohio 2010) (cited in Bostic, 439 S.W.3d at 339 n.24) (stating that under a no-threshold theory of carcinogenesis, "it would be just as likely that ambient benzene" rather than benzene in refinery emissions caused plaintiffs' blood and lymph cancers); Henricksen v. ConocoPhillips Co., 605 F. Supp. 2d 1142, 
The competing cause model goes hand-in-hand with but-for causation. Why does it matter if a plaintiff cannot exclude, say, ambient asbestos as a cause of mesothelioma? Because if ambient asbestos "really" was "the" cause of the cancer, then the plaintiff would have been sick even absent the exposure for which defendant was responsible. When it invoked a competing cause model to reject the "any exposure" theory, the Supreme Court of Texas implicitly applied a standard of but-for causation that the court explicitly rejected in its next breath. ${ }^{178}$

Comparing Bostic to two Tenth Circuit uranium mining cases makes this clear. ${ }^{179}$ In the mining cases, the plaintiffs' experts attempted to quantify the radiation dose each plaintiff received from the defendant's operations, to attribute to that dose a fraction of each plaintiff's overall disease risk, and to opine that each such fraction was a substantial contributing factor to each plaintiff's disease. ${ }^{180}$ In each case the court expressly held that such testimony could not suffice because no witness testified that but for the mining and milling radiation the plaintiffs would not have become ill; substantial factor causation did not displace but-for causation. ${ }^{181}$ By contrast, Bostic purported to accept substantial factor causation while using but-for logic. ${ }^{182}$

To bolster its argument that small asbestos exposures cannot be factual causes of mesothelioma, the Bostic majority emphasized the dose-dependence of mesothelioma risk. ${ }^{183}$ Plaintiffs' experts all agreed that the greater the cumulative exposure, the greater the risk, although they also all agreed that very low

1162-63 (E.D. Wash. 2009) (holding that plaintiff failed to show his [leukemia] was caused by exposure to benzene in gasoline fumes as opposed to "idiopathic" origin); Tompkin v. Philip Morris USA, Inc., 362 F.3d 882, 894 (6th Cir. 2004) (explaining that jury apparently believed that asbestos exposure rather than cigarette smoking caused plaintiff's lung cancer).

178. See Bostic, 439 S.W.3d at 342 ("For these reasons, we extend the reasoning and holdings of Flores to mesothelioma cases, including our rejection of the 'any exposure' theory of liability, with the clarifications discussed below.") The first "clarification," which followed immediately after the sentence just quoted, was to reject a requirement of proof of but-for causation. $I d$. (noting the court's concern that "the court of appeals' decision might be read to require satisfying a proof requirement that but for Bostic's exposure to Georgia-Pacific's products, he would not have contracted mesothelioma").

179. See e.g., Wilcox, 619 F.3d 1165; June, 577 F.3d 1234.

180. Wilcox, 619 F.3d at 1170-71 (Lucero, J., concurring); June, 577 F.3d at 1237.

181. Wilcox, 619 F.3d at 1168; June, 577 F.3d at 1245. By focusing on the Tenth Circuit's clarity in these cases, I do not mean to imply that I think their rule is the best choice. See Gold, supra note 85, at 250-52 (criticizing Wilcox and June).

182. It might be possible to distinguish Bostic from Wilcox and June based on the quantum of evidence of exposure adduced: in the uranium mine cases the plaintiffs attempted to quantify the exposure to radiation from defendants' operations, while in Bostic the court held that the plaintiffs failed utterly to quantify the dose. However, this distinction is beside the point here. Bostic, no less than Wilcox and June, applied a competing cause model. Bostic implies that even a quantified dose of defendant's asbestos, if small enough, could not be considered a cause-in-fact.

183. Bostic, 439 S.W.3d at 338-39. 
exposure levels can also cause mesothelioma. ${ }^{184}$ One went so far, as described by the court, to testify that "background levels are sufficiently low that they do not cause disease." 185 The majority saw this testimony as fatally in conflict with the "any exposure" theory: "If any exposure at all were sufficient to cause mesothelioma, everyone would suffer from it or at least be at risk of contracting the disease." 186

As the dissenters pointed out, "[t]his statement misunderstands the expert testimony regarding the nature of mesothelioma." 187 The first part of it-that if any exposure could cause mesothelioma, "everyone would suffer from it"-is utter nonsense. We should all be thankful that exposure to asbestos that is sufficient to cause mesothelioma does not always cause mesothelioma. If it did, this horrific disease would be vastly more common than it is. Even among those with heavy occupational exposure, the incidence of mesothelioma is relatively modest. ${ }^{188}$

The second part of the court's statement-that if any exposure to asbestos could cause mesothelioma, "everyone would . . . be at risk of contracting the disease"-is perfectly consistent with the evidence in the case. ${ }^{189}$ As the court noted immediately before that sentence, plaintiffs" experts relied in part on "a report stating that "[m]esothelioma can occur in cases with low asbestos exposure. However, very low background environmental exposures carry only an extremely low risk." 190 Thus, everyone is, more or less, at risk of mesothelioma even from background exposures. It is just that those risks are very, very small. ${ }^{191}$ One reason offered by plaintiffs' experts in Bostic is that

184. See generally id. at 356-58 (describing the expert testimony).

185. Id. at 339 n.22 (quoting plaintiffs' expert witness Dr. Brody: "background [is] ... [the amount of asbestos] we all have . . . in the lung to some level, which does not produce disease. That's not a level that anyone can measure disease"). A plausible interpretation of this testimony is that the increased risk caused by background exposures is so low it cannot be detected by epidemiologic study; moreover, because "we all" have background levels of asbestos in our lungs, no "unexposed" control group could be found against which to measure the effect of "background" exposures.

186. Id. at 339.

187. Id. at 374 (Lehrmann, J., dissenting).

188. See Osteen v. A.C. \& S., Inc., 307 N.W.2d 514, 518 (Neb. 1981) (noting that among asbestos workers, incidence of mesothelioma is approximately seven percent); Thompson, supra note 10, at 4 (stating that mesothelioma affects "only about 5\%" of exposed people); TOD ZuCKERMAN \& MARK RASKOFF, 3 ENVIRONMENTAL INSURANCE Litigation: LAW AND PRACTICE § $26: 5$ n.5 (2010) (quoting Mark H. Beers et Al., The Merck Manual of Diagnosis and TherAPY 472 (Robert S. Porter \& Thomas V. Jones eds., 18th ed. 2006)) (noting that asbestos workers have up to ten percent lifetime risk of developing mesothelioma).

189. Bostic, 439 S.W.3d at 339.

190. Id. (emphasis added).

191. In re Asbestos Litig., 900 A.2d 120, 132 (Del. Super. Ct. 2006) (“[B]ackground incidence rate [of mesothelioma] is basically zero."); Boston, supra note 122, at 294 (stating incidence of mesothelioma in general population is approximately two per million). Some courts have found it 
"[w]hen the exposure is only at background levels, 'we tend to keep up and it's not a problem." ${ }^{192}$ But the risk is still not zero, perhaps because certain individuals bear one or more genetic mutations that make them less able to resist, repair, or root out the DNA damage that asbestos wreaks to lead mesothelium cells down the path to malignant transformation. ${ }^{193}$

Similarly, the fact that "[e]xposure to asbestos, a known carcinogen, is never healthy but fortunately does not always result in disease" 194 also does not mean that low levels of exposure cannot cause mesothelioma. ${ }^{195}$ It does not matter whether mesothelioma was inevitable given Bostic's aggregate level of exposure. Some, perhaps many, people with similar exposures would not develop mesothelioma, but Bostic did. ${ }^{196}$ In implying that Bostic's exposure to GeorgiaPacific's products might be one of the times when exposure "does not ... result in disease," the majority again functionally framed the issue as whether the

possible to quantify the background risk and to assess the incremental risk contribution of relatively small above-background exposures. Sienkiewicz v. Greif, [2011] UKSC 10, [107-12], [2011] 2 WLR 523 (appeal taken from Eng.) (Lord Phillips) (describing trial court finding that small occupational exposure increased mesothelioma risk by $18 \%$ above background risk for secretary who worked in office portion of factory where asbestos was used).

192. Bostic, 439 S.W.3d at 374 (Lehrmann, J., dissenting) (quoting plaintiff's expert witness).

193. R.M. Rudd, Malignant Mesothelioma, 93 BRIT. MED. Bull. 105, 108 (2010); see also Jennifer E. Below, Factors that Impact Susceptibility to Fiber-Induced Health Effects, $14 \mathrm{~J}$. Toxicology ENVTL. HeAlth 246, 254 (2011) (suggesting that genome-wide association studies would likely reveal genetic susceptibility factors); Aki Murakami et al., Heme Oxygenase-1 Promoter Polymorphism is Associated with Risk of Malignant Mesothelioma, 1 Lung 333 (2012); Xu et al., supra note 11, at 4389, 4395-96 (2014) (reporting experimental results consistent with the hypothesis that a genetic mutation makes individuals more susceptible to mesothelioma after even low levels of asbestos exposure, rather than the hypothesis that the mutation causes individuals to develop mesothelioma even without exposure to asbestos); Joseph R. Testa et al., Germline BAP1 Mutations Predispose to Malignant Mesothelioma, 43 NATURE GENETICs 1022, 1022, 1025 (2011) (reporting that mutations in a gene that codes for a tumor suppressor protein may be associated with heightened risk of several cancers even without asbestos exposure, but predominantly mesothelioma if asbestos exposure is present).

194. Bostic, 439 S.W.3d at 339-40 (quoting Flores v. Borg-Warner Corp., 232 S.W.3d 765, 770-71(Tex. 2007)).

195. See id. at 375 (Lehrmann, J. dissenting) ("To state that any exposure to asbestos is not sufficient to cause mesothelioma, simply because every person has not developed mesothelioma, is to ignore the testimony of the expert witnesses at trial and to misunderstand fundamentally the nature of the disease.").

196. The overall risk of mesothelioma, even among occupationally exposed workers, is small. See supra text accompanying note 191. As noted above, see supra text accompanying note 193, research increasingly supports the hypothesis that certain genetic variations make some individuals particularly susceptible to asbestos-induced mesothelioma, even at low exposure levels. See also Bostic, 439 S.W.3d at 375 (Lehrmann, J., dissenting) (noting that development of mesothelioma after asbestos exposure depends on at least two stochastic factors: transport of fibers to the pleura and genetic factors that affect individual susceptibility to asbestos). 
disease would have been avoided but for Bostic's exposure to Georgia-Pacific's products. ${ }^{197}$

In its effort to avoid finding causation, the court implicitly assumed what may be true but science has not yet demonstrated - that there is some level of exposure to asbestos that is incapable of causing mesothelioma: ${ }^{198}$ hence the majority's insistence that the so-called any exposure theory contradicts the asserted inability of ambient background levels of asbestos fibers to produce the disease. ${ }^{199}$ Ironically, however, the existence of a no-effect threshold would tend to support a finding that asbestos from Georgia-Pacific's product was a but-for cause of Bostic's mesothelioma. ${ }^{200}$ If Bostic's exposure to Georgia-Pacific's asbestos was a necessary element of the set of exposures that collectively exceeded the threshold and caused mesothelioma, then it was a but-for cause of the disease. ${ }^{201}$ Even if the aggregate exposure from other sources exceeded the threshold without Georgia-Pacific's contribution-meaning that GeorgiaPacific's asbestos was not, strictly speaking, necessary for the harm to occur-Georgia-Pacific's contribution could still be a factual cause under the multiple sufficient cause rule. ${ }^{202}$

The Bostic majority did not embrace or even articulate the above reasoning. But it did attempt an alternative justification for insulating contributors of small exposures from findings of factual causation. In a move that proved too much even for one justice who concurred in the result, the majority used another shift in its causal paradigm to ensure that a contributing cause model will be unavailable to Texas courts in mesothelioma cases.

3. Comparing Exposures: Mixing Norm and Fact in a Concurring Cause Model.--In rejecting the "any exposure" theory of causation, the Bostic majority relied principally on a competing cause model, implicitly rejecting the idea that small exposures, by contributing to mesothelioma risk, could combine with other

197. Bostic, 439 S.W.3d at 339-40.

198. See id. at 340 (characterizing "any exposure theory" as premised on "a failure of science to determine the maximum safe dose of a toxin"). Plaintiffs' expert witnesses accepted that a noeffect threshold theoretically may exist, but testified that such a threshold has not been identified "because that level is so low that we have not been able to measure it." Id. at 368 (Lehrmann, J. dissenting) (quoting testimony of plaintiffs' witness Dr. Lemen). Georgia-Pacific did not dispute this assertion, but rather embraced it as grounds for affirmance. See Georgia-Pacific Corp.'s Brief on the Merits, supra note 50, at 2 (stating that plaintiffs' expert admitted he could not identify a minimum threshold of exposure that would lead to mesothelioma); id. at 29 \& n.26 (arguing plaintiffs must prove that threshold which "must, at a minimum, be higher than the background level of asbestos.").

199. Bostic, 439 S.W.3d at 339.

200. This assumes, of course, that there was sufficient evidence for the jury to conclude that Bostic was exposed to at least some amount of asbestos from Georgia-Pacific's products.

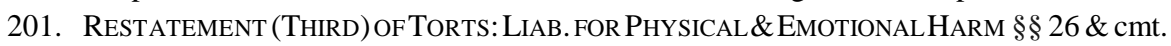
c, $28 \&$ cmt. c (2010).

202. Id. $\$ 27 \mathrm{cmt} . \mathrm{f}, \mathrm{g}$. 
(large or small) exposures to cause the disease. ${ }^{203}$ In providing a further rationale for its decision, however, the majority switched gears once again:

Further, there are cases where a plaintiff's exposure to asbestos can be tied to a defendant, but that exposure is minuscule as compared to the exposure resulting from other sources. . . . The Restatement Third of Torts provides that " $[\mathrm{w}]$ hen an actor's negligent conduct constitutes only a trivial contribution to a causal set that is a factual cause of harm under $\S 27$ [addressing multiple sufficient causes], the harm is not within the scope of the actor's liability." 204

By quoting from section 36 of the Restatement Third, the majority betrayed yet another switch in causal model as well as a move from factual to normative reasoning.

The quoted Restatement section applies to conduct that "constitutes ... a . . contribution," albeit a "trivial" one, "to a causal set that is a factual cause of harm." ${ }^{05}$ Thus, where the Bostic majority contended in the immediately adjacent paragraphs that a small exposure to asbestos could not be a factual cause of mesothelioma, ${ }^{206}$ in invoking the "trivial contribution" rule the majority shifted to a model in which a small exposure is a factual cause, although only in combination with other exposures-a classic case of concurring causes. ${ }^{207}$ Concurring causes that combine to bring about harm are all factual causes of the harm. ${ }^{208}$ Yet the Bostic majority ignored the concurring cause model in the rest

203. Bostic v. Georgia-Pacific Corp., 439 S.W.3d 332, 338 (Tex. 2014).

204. Id. at 341 (quoting Restatement (ThiRd) OFTORTs: Liab. FOR PHYSICAL \& EMOTIONAL HARM $§ 36$ (2010) (ellipsis added, footnote omitted, bracketed material in original).

205. Id. at 345 (emphasis added).

206. See, e.g., id. at 340 (arguing that the "any exposure" theory "negates the plaintiff's burden to prove causation by a preponderance of the evidence"); $i d$. at 341 (arguing that if small background exposures are not factual causes of mesothelioma, then small exposures from use of specific products must not be factual causes either).

207. See Restatement (ThiRd) OFToRts: Liab. FOR PhysicAl \& EMOTIONAL HARM $\S 36 \mathrm{cmt}$. a (2010) ("[T]he conduct still constitutes a factual cause under $\S 27$ and Comment $f$ ').

208. See id. $\S 26 \mathrm{cmt}$. c (“An actor's tortious conduct need only be $a$ factual cause of the other's harm. The existence of other causes of the harm does not affect whether specified tortious conduct was a necessary condition for the harm to occur.") (emphasis in original). A complication is that the trivial contribution rule of section 36 applies only to overdetermined causation. See id. $\S 36 \mathrm{cmt}$. b ("The exception applies only when there are multiple sufficient causes and the tortious conduct at issue constitutes a trivial contribution to any sufficient causal set."). Thus the reasoning of sections 27 and 36 of the Restatement Third works as follows. (1) Section 27 says that if multiple sufficient causes exist, each is treated as a cause-in-fact even though none is literally a but-for cause. Thus if it takes 1000 units of a poison to cause a disease and two tortfeasors each administer 1000 units before the disease develops, both tortious acts are factual causes of the disease. (2) Comment $\mathrm{f}$ to section 27 explains that the rule applies to multiple sufficient causal sets, so each cause need not be entirely sufficient in itself. Thus if three tortfeasors each administer 667 units of the poison, each tortious act is a factual cause of the disease. $C f$. id. $\S 27 \mathrm{cmt}$. f, illus. 3. (3) Section 
of its opinion. ${ }^{209}$

Moreover, the Restatement section does not say that a trivial contributor to a sufficient causal set is not a factual cause of the plaintiff's injury, but rather that for actors responsible for trivial contributions, "the harm is not within the scope of the actor's liability" - an explicitly normative determination. ${ }^{210}$ The majority must have known that it was invoking a normative rule because in holding that "but-for" causation was not required, the majority cited comment $g$ to section 27 of the Restatement Third as "the scenario closest to our case." 211 Comment $\mathrm{g}$ instructs that if a plaintiff is exposed to multiple doses of a toxic agent, each dose "is a factual cause of the person's disease under the [multiple sufficient cause] rule of this section"-even if some doses may not have been but-for causes because "the person may have been exposed to doses in excess of the threshold" required to produce disease. ${ }^{212}$ The majority ignored that reasoning-preferring to hold that a contributing dose may only be considered a factual cause if it is alone sufficient to produce disease under doubling-plus logic_but nevertheless quoted it. The quotation, however, left out the comment's final sentence: "Whether there are some exposures that are sufficiently de minimis that the actor should not be held liable is a matter not of factual causation, but rather of policy, and is addressed in $\S 36 .{ }^{, 213}$

Several of the majority's holdings that appear to be addressed only to factual causation could be understood as normative judgments when seen through the

36 applies to protect those who contribute only trivially to any of multiple sufficient causal sets from liability. Thus if two tortfeasors each administer 999 units of the poison and a third tortfeasor administers 1 unit, the third tortfeasor may not be liable. The third tortious act is a cause-in-fact under section 27, because there exist two sufficient causal sets (each of 999+1 units) of which the 1-unit contribution is an essential element. But the harm is overdetermined, because the total dose of 1999 units exceeds the 1000-unit threshold. Moreover, there exists a third sufficient causal set (of 999+999 units) that does not include the 1-unit contribution. Section 36 states that under such circumstances, for policy reasons a factfinder or a court may excuse the tortfeasor that administered the trivial contribution.

209. See generally supra Parts II.A, II.B.1, II.B.2.

210. See Restatement (ThiRd) ofTorts: Liab. FOR PhysicAl \& EMOtional Harm $\S 36 \mathrm{cmt}$ b. reporters' note (2010) (noting that "this limitation on liability is a normative one rather than a factual one."). The Restatement Third thus positions the "trivial contributions" rule amid other legal rules that withhold liability even for tortious conduct that is a factual cause of a plaintiff's harm, denominated "scope of liability" in the Restatement Third and often called "proximate cause" elsewhere. See id. ch. 6, Special Note on Proximate Cause; see also id. $\S 27 \mathrm{cmt}$. g (stating that $\S$ 36 treats "a matter of ... policy").

211. Bostic, 439 S.W.3d at 346.

212. Restatement (Third) of Torts: Liab. For Physical \& EMotional Harm $\S 27 \mathrm{cmt}$. $\mathrm{g}$ (2010); see also id. $\S 27 \mathrm{cmt}$. $\mathrm{f}$ (stating that in overdetermined causation situations, a tortious act may be considered a cause-in-fact even if "an actor's conduct requires other conduct to be sufficient to cause another's harm").

213. Id. $\S 27 \mathrm{cmt}$. g. 
lens of the "trivial contributions to multiple sufficient causes" rule. ${ }^{214}$ First, the majority implicitly made the threshold policy judgment described in comment $\mathrm{g}$ to Restatement section 27: that there are asbestos exposures sufficiently small that the actors responsible for them should not be liable. ${ }^{215}$ Second, the majority made a policy judgment about the proof required to avoid having a defendant's exposure treated as de minimis: quantifying (although not "with mathematical precision") the dose contributed by each defendant as well as the plaintiff's total dose. ${ }^{216}$ Third, the majority made a policy judgment about the minimum dose that can be "substantial"-hence, not trivial: the defendant-specific dose must, itself, more than double the risk of disease. ${ }^{217}$

The defendant-specific doubling-plus rule, of course, is utterly inconsistent with the concurring cause model from which the trivial contribution rule is derived. Yet after its doubling-plus ruling, the Bostic majority invoked the trivial contribution rule a second time:

[W] hen evidence is introduced of exposure from other defendants or other sources, proof of more than a doubling of the risk may not suffice to establish substantial factor causation. In the Restatement Second of Torts, .. . substantial factor causation "denote[s] the fact that the defendant's conduct has such an effect in producing the harm as to lead reasonable men to regard it as a cause, using that word in the popular sense, in which there always lurks the idea of responsibility .... Along the same lines, the Restatement Third recognizes that a defendant's trivial contribution to multiple causes will not result in liability.

Suppose a plaintiff shows that his exposure to a defendant's product more than doubled his chances of contracting a disease, but the evidence at trial also established that another source of the toxin increased the chances by a factor of 10,000 . In this circumstance, a trier of fact or a court reviewing the sufficiency of the evidence should be allowed to conclude that the defendant's product was not a substantial factor in causing the disease. ${ }^{218}$

This hypothetical has much intuitive appeal if the different exposures' contributions to relative risk are assumed to be additive. Examination reveals, however, that the reasoning behind the hypothetical is neither consistent with the rest of the Bostic majority opinion nor compelled by the Restatement Third provision the majority cited.

The majority's hypothetical treated two independent exposures as together constituting the one and only causal set of exposures. But the hypothetical

214. For brevity, this rule is hereinafter referred to as the "trivial contribution" rule, but the qualifier "to multiple sufficient causes" is important.

215. Bostic, 439 S.W.3d at 338.

216. Id.

217. Id. at 356 .

218. Id. at 350-51. 
actually embraced three distinct sufficient causal sets: the set consisting of both exposures combined, the set consisting only of the "giant" exposure that caused a 10,000-fold increased risk, and the set consisting only of the "challenged" exposure that just more than doubled the risk.

How can the challenged exposure, which is so small compared to the giant exposure, itself constitute a sufficient causal set? By more than doubling the risk. The doubling-plus rule logically implies that the challenged exposure was sufficient to be a "more likely than not" cause of mesothelioma in the hypothetical plaintiff even in the absence of the giant exposure. Thus the Bostic majority's hypothetical does not involve a trivial contribution to a set of exposures that together overdetermine the harm. ${ }^{219}$ The hypothetical involves two independent sufficient causes, analogous to a two-fire case in which one fire is much bigger than the other, but either alone would still burn down the house. Another analogy would be two negligent shooters who simultaneously fire in plaintiff's direction. One fires a single rifle shot that pierces the victim's heart; the other empties a machine gun's ammunition belt into the victim. In all of these analogous situations, each of the multiple sufficient causes is a cause-in-fact of the harm that occurs. ${ }^{220}$

Yet the intuition rebels at the toxic exposure hypothetical, because the enormity of the giant exposure makes it seem seems much more probable that the giant exposure was the source of the molecules (or fibers) that actually interacted with the plaintiff's cells to cause disease. ${ }^{221}$ However, the doubling-plus rule

219. See Restatement (ThiRd) OFToRTs: Liab. FOR PhysicAl \& EMOTIONAL HARM $\S 36 \mathrm{cmt}$. b (2010) ("The exception applies only when there are multiple sufficient causes and the tortious conduct at issue constitutes a trivial contribution to any sufficient causal set.") (emphasis added). In the Bostic majority's hypothetical, the challenged exposure is a trivial contribution to the causal set that includes both exposures, but it is a non-trivial contribution to the sufficient causal set that includes only itself. In this respect the Bostic hypothetical is very different from the Restatement Third's illustration of the trivial contribution rule. In the illustration, a mesothelioma plaintiff who worked in construction was exposed to eleven manufacturers' asbestos fibers "on a daily basis for years," with an overall exposure over forty years that "was considerably more than required to cause Jerry's mesothelioma." Id. $\S 36 \mathrm{cmt}$. b, illus. A twelfth defendant's product was used "in a single day, on a different floor" from plaintiff's work site. $I d$. The illustration explicitly assumes that a threshold exposure is required to cause mesothelioma and implicitly assumes that the "single day, different floor" exposure did not exceed that threshold.

220. Id. § 27.

221. The Bostic majority's hypothetical should be distinguished from certain "[s]pecial cases" discussed in the Restatement Third that also involve causes of dramatically different magnitude. Id. $\S 27 \mathrm{cmt}$. i. These special cases involve causal contributions that become necessary elements of sufficient causal sets only by disaggregating the much larger contributions of other parties. Perhaps the easiest example given in the Restatement is an enormous unforeseeable flood that breaches a negligently constructed dam that would have given way in a normal flood. The bad dam becomes a necessary element of a sufficient causal set only by hypothesizing a flood smaller than the one that took place. Id. An analogous toxic tort example might involve two defendants who contribute doses of 1500 and 500 units, respectively, of a toxin with a causal threshold of 1000 units. The smaller 
acknowledges that determining the actual culprit molecules is impossible and uses doubling the risk as a proxy for causal sufficiency. One might as well ask which fire supplied the specific flames that consumed the plaintiff's house.

Does it seem unfair that the source of the challenged exposure should be liable in the face of the existence of the giant exposure? A partial answer is that it is also unfair to absolve a tortious sufficient cause because of the happenstance of a much worse tort or a much larger cause. ${ }^{222}$ A better answer, supplied in Bostic by Justice Guzman's concurring opinion, is that in most jurisdictions comparative responsibility doctrines can adjust the shares of liability borne by the two causes. ${ }^{223}$

This is not to argue that the trivial contribution rule should never be applied in cases of overdetermined harm involving multiple sufficient causal sets. However, when applied the rule should be explicitly recognized as a policy choice. The Bostic majority's discussion of the legal significance of the relative contributions of multiple sources of toxic exposure invoked a normative rule in the guise of providing factual causation standards. It implied a concurring cause model that the remainder of the majority opinion eschewed. And it applied that rule to a hypothetical situation outside the rule's literal scope.

4. "Direct" Evidence: The Alternative that Isn't.-According to both Havner and the opinions of all nine justices in Bostic, under Texas law, epidemiology functions as an "alternative" method of proving causation "[i]n the absence of direct, scientifically reliable proof of causation." 224 But what might constitute "direct, scientifically reliable proof of causation"? Havner hinted that "controlled scientific experiments" might sometimes "determine if a substance is capable of causing a particular injury or condition" and "objective criteria" would help "determine[ ] with reasonable certainty that a particular individual's injury was caused by exposure to a given substance.",225

Animal and in vitro studies are controlled experiments, but Havner itself demonstrated reluctance to infer general causation from such studies absent epidemiologic support. ${ }^{226}$ Yet, as Havner also recognized, researchers generally

contribution is not sufficient to cause harm and would only be necessary to cause harm if the larger contribution had been below the threshold. See id. The Bostic majority's hypothetical assumes that both exposures were sufficient causes under the doubling-plus test. Moreover, the Restatement notes that these special cases "are difficult to explain" and specifically questions their appropriateness in cases of overdetermined toxic causation. See id.

222. This of course is an important part of the rationale for the multiple-sufficient-cause rule in general. See id. $\S 27 \mathrm{cmt}$. c (describing the rationale but pointing out that causal fortuity often allows persons who commit otherwise tortious acts to avoid liability).

223. Bostic, 439 S.W.3d at 365 (Guzman, J., concurring).

224. Merrell Dow Pharm., Inc. v. Havner, 953 S.W.2d 706, 715 (Tex. 1997); see also Bostic, 439 S.W.3d at 348 (quoting Havner); id. at 360 (Guzman, J., concurring) (Havner allowed use of "scientific rather than direct proof"); id. at 371 (Lehrmann, J., dissenting) (agreeing with majority's distinction between direct and epidemiologic evidence).

225. Havner, 953 S.W.2d at 714-15.

226. See id. at 728-29 (holding that animal studies did not support inference of causation). 
cannot and will not expose human beings to controlled experiments with suspected toxins. ${ }^{227}$ The notable exception is drug clinical trials, for which the potential benefit can justify the risk with informed consent. However, although clinical trials are experimental, they are also fundamentally epidemiologic — and the Supreme Court of Texas treats them as such. ${ }^{228}$ Therefore, it is hard to see what might qualify as "controlled experimentation" to satisfy the "direct evidence" alternative to epidemiologic evidence as proof of general causation. ${ }^{229}$ It is equally hard to see what might qualify as "objective criteria" to serve as "direct evidence" of specific causation, except in the unusual case of a signature disease. ${ }^{230}$

The Bostic majority seemed to admit this. The majority responded as follows to the dissent's argument ${ }^{231}$ that the Bostic plaintiffs proved causation by direct evidence (and therefore did not need to produce epidemiologic evidence satisfying the doubling-plus rule):

If the plaintiff can establish with reliable expert testimony that (1) his exposure to a particular toxin is the only possible cause of his disease, and (2) the only possible source of that toxin is the defendant's product (or, in another of the dissent's hypotheticals, the products of two defendants whose combined doses established the required threshold dose to cause disease), this proof might amount to direct proof of causation and the alternative approach embraced in Havner might be

227. Id.

228. See Merck \& Co. v. Garza, 347 S.W.3d 256, 260 (Tex. 2011) (describing the trial court's view that a clinical trial relied on by plaintiffs satisfied the doubling-plus rule); $i d$. at 263-64 (noting that clinical trials apply epidemiologic methods in an experimental rather than observational setting; holding that the doubling-plus rule applies to clinical trials).

229. Studies of toxic modes of action at a subcellular and molecular scale offer some potential to provide experimental evidence of general causation. Since Havner was decided, advances in toxicogenomics and related fields have made it increasingly possible for researchers to detect the ways in which exposure to various substances affect the structure of DNA and chromosomes, the expression of genes, and epigenetic factors associated with DNA. See generally Steve C. Gold, The More We Know, the Less Intelligent We Are? How Genomic Information Should, and Should Not, Change Toxic Tort Causation Doctrine, 34 HARV. EnvTL. L. REV. 369 (2010). Often, however, such mechanistic evidence confirms the causal nature of observed epidemiologic associations. Mechanistic evidence standing alone as proof of general causation has yet to attain significant acceptance from courts. But see Milward v. Acuity Specialty Prod. Grp., 639 F.3d 11, 26 (1st Cir. 2011) (holding that the trial court should have admitted expert testimony about "weight of the evidence" causation analysis based primarily on mechanistic studies).

230. The development of valid biomarkers of sufficient sensitivity and specificity might someday provide more definitive evidence of specific causation, but so far that potential has been little realized, and it is unclear how fully it ever will be. See generally Gold, supra note 229; Gold, supra note 85 .

231. Bostic v. Georgia-Pacific Corp., 439 S.W.3d 332, 367-68, 376 (Tex. 2014) (Lehrmann, J., dissenting). 
unnecessary. ${ }^{232}$

The Bostic majority thus squeezed the possibility of direct evidence of causation into a very a small space indeed. But even in doing so, the majority reasoned inconsistently.

In responding to the dissent, the Bostic majority asserted that for a signature disease, proof that two defendants contributed doses that combined to reach the disease-causing threshold would constitute direct evidence of causation for each defendant. This response cannot be reconciled with the majority's insistence that each defendant's product must more than double the plaintiff's risk of disease.

The Bostic majority nevertheless rejected the dissent's complaint that the doubling-plus rule made no sense in a context of multiple exposures to the same toxic agent. ${ }^{233}$ In doing so the majority relied on a burden that the Havner court, with scant analysis, put on plaintiffs: even after producing multiple epidemiologic studies showing statistically significant results satisfying the doubling-plus rule, "if there are other plausible causes of the injury or condition that could be negated, the plaintiff must offer evidence excluding those causes with reasonable certainty." 234 The Bostic majority reasoned:

If exposure from other sources were irrelevant when we decided Havner, we would not have stated that other causes of the disease should be excluded, a requirement we actually relax in today's case because of the special difficulties encountered in multiple-exposure cases .... But we think Havner's requirement of proof of a more than doubling of the risk is particularly useful in multiple-exposure cases where the alternative is to abdicate resort to scientifically reliable proof and accept that any exposure will suffice. ${ }^{235}$

Like so much of the Bostic majority opinion, the above reasoning confused distinct causal models. Havner, besides turning on general agent-disease causation rather than specific causation, explicitly involved a competing cause model ${ }^{236}$ It might make sense to treat separate exposures to the same agent as competing causes based on a model positing that one and only one exposure caused the disease and that plaintiff must prove which of multiple exposures was "the one." But the Bostic majority disavowed that approach in favor of substantial factor causation - which is why it relaxed the requirement to exclude other causes. It makes no sense to require exclusion of supposedly competing causes that are really - as a matter of fact or as a matter of the law's causal model-contributors to the same risk. ${ }^{237}$

232. Id. at 352 .

233. Id. at 352-353.

234. Merrell Dow Pharm., Inc. v. Havner, 953 S.W.2d 706, 720 (Tex. 1997).

235. Bostic, 439 S.W.3d at 352.

236. See Havner, 953 S.W.2d at 352 (noting that experts for both sides agreed that some birth defects are genetically caused and that the cause of a large percentage of birth defects is unknown).

237. See Sienkiewicz v. Greif, [2011] UKSC 10 [93, 104], [2011] 2 A.C. 229 (appeal taken 


\section{Further Reflections on the Strange Career of The Doubling-Plus Rule}

Although policy considerations largely may have driven the holdings in Bostic, the majority's confusion about the doubling-plus rule can also be traced to doctrinal confusion in Texas toxic tort precedent. Reviewing the history that led up to Bostic offers lessons about the doubling-plus rule, the evolution of doctrine, and the dialogue between legal scholarship and case law.

\section{A. A Brief Early History of the Doubling-Plus Rule, Before Havner}

Although courts in the first half of the twentieth century occasionally encountered population-based epidemiologic reasoning on the cause of disease, ${ }^{238}$ the doubling-plus rule first appeared in a published judicial opinion in 1982. ${ }^{239}$ The case, Cook v. United States, involved claims that the swine flu vaccine caused a plaintiff's Guillain-Barré Syndrome (GBS). ${ }^{240}$

In retrospect, in light of all that has been written about the doubling-plus rule ${ }^{241}$ the most remarkable thing about Cook is the casualness with which the court announced the rule. Having concluded that "causation in these actions turns on the interpretation of the CDC statistical data" measuring the rate of GBS in vaccinated and unvaccinated populations, the court simply observed that

from Eng.) (Lord Phillips) (contrasting application of the doubling-plus rule to competing, as opposed to "cumulative," causes).

238. The earliest cases involved environmental exposure to typhoid bacteria in public water supplies. See Martin v. Springfield Water Co., 128 S.W.2d 674, 678-79 (Mo. App. 1939) (holding that the trial court properly admitted expert testimony over defendant's objection that expert was not qualified to give epidemiologic opinion; a witness opined, in response to a hypothetical question that included assumptions about the number of cases of typhoid in the community, that contaminated water caused plaintiff's typhoid); Safransky v. City of Helena, 39 P.2d 644 (Mont. 1935) (describing epidemiologist's testimony of the number of cases of typhoid in years before, during, and after the period in which a water supply pipe was subject to contamination by sewage; causation issue not before the court); Lovich v. Salvation Army, 75 N.E.2d 459 (Ohio App. 1947) (holding that the trial court incorrectly held that epidemiologist's testimony established as a matter of law that food preparation by an infected individual was the cause of plaintiffs' typhoid). Even earlier cases about typhoid involved rudimentary epidemiologic ideas, but not the term epidemiology. See Missouri v. Illinois, 200 U.S. 496 (1906) (noting, in dismissing Missouri's nuisance claim that alleged that a canal carrying sewage from Chicago caused an observed increase in the number of typhoid cases in Saint Louis, that other sources of typhoid bacteria existed); Stubbs v. City of Rochester, 124 N.E. 137 (N.Y. 1919) (holding that plaintiff who proved exposure to contaminated drinking water did not have to rule out all other possible causes of typhoid to recover).

239. See Carruth \& Goldstein, supra note 145, at 199.

240. Cook v. United States, 545 F. Supp. 306 (N.D. Cal. 1982).

241. For a sampling of the scholarly commentary on the doubling-plus rule just up to 2000 , see Carruth \& Goldstein, supra note 145, at 196 n.4. 
"[w]henever the relative risk to vaccinated persons is greater than two times the risk to unvaccinated persons, there is a greater than $50 \%$ chance that a given GBS case among vaccinees of that latency period is attributable to vaccination, thus sustaining plaintiff's burden of proof on causation." 242 A few months later, another federal district court deciding a swine flu case applied the doubling-plus rule with only slightly more explication. ${ }^{243}$

The numerous swine flu cases, as it happened, provided an ideal environment for the uncontested adoption of a rule equating more than doubling of risk with causation more likely than not in an individual case. Epidemiology provided virtually all of the evidence connecting swine flu vaccine and GBS. ${ }^{24}$ The relative risk was so high and the statistical association was so strong, however, that the risk of GBS was central to the government's decision to end the nationwide swine flu vaccination program. ${ }^{245}$ Therefore, it would have been hard for defense attorneys to argue that there was insufficient proof of general causation. But because the relative risk peaked soon after vaccination and then declined toward the baseline rate in the unvaccinated population, ${ }^{246}$ specific causation was much in doubt in GBS cases that occurred more than a few weeks after vaccination. Eventually the government stipulated to liability in cases with an onset earlier than the cut-off point for relative risks greater than two (according to the epidemiologic study the government accepted) and contested, largely successfully, claims in which the GBS appeared later than that. ${ }^{247}$

Allen v. United States, ${ }^{248}$ decided in 1984, was much more complicated. The plaintiffs in Allen alleged that above-ground nuclear weapons tests by the United

242. Cook, 545 F. Supp. at 308 (emphasis added). The parties agreed that a relative risk value of two would sharply divide successful causal claims from unsuccessful ones; they disagreed only about how to compute the applicable relative risk value. $I d$.

243. Padgett v. United States, 553 F. Supp. 794, 800-01 (W.D. Tex. 1982) ("From the relative risk, we can calculate the probability that a given case of GBS was caused by vaccination . . A relative risk of 2 or greater... means that the probability that vaccination caused a particular case of GBS is better than $50 \%$. Hence, a relative risk of 2 or greater would indicate that it was more likely than not that vaccination caused a case of GBS.") The court made a slight error in that a relative risk of exactly two implies an attributable fraction of $50 \%$ rather than greater than $50 \%$.

244. David A. Freedman \& Philip B. Stark, The Swine Flu Vaccine and Guillain-Barre Syndrome: A Case Study in Relative Risk and Specific Causation, 64 L. \& Contemp. Probs. 49 (2001) (noting that twenty-five years after the swine flu vaccine program, whether the association was causal is still controversial); Arnold W. Reitze, Jr., Federal Compensation for Vaccination Induced Injuries, 13 B.C. ENVTL. AFF. L. REV. 169, 182 (1986) (etiology unknown in 1970s).

245. Reitze, supra note 244 , at 180.

246. See Freedman \& Stark, supra note 244, at 53.

247. Cook, 545 F. Supp. at 307 (describing stipulation); Bert Black \& David E. Lilienfeld, Epidemiological Proof in Toxic Tort Litigation, 52 FORDHAM L. REV. 732, 774 (1984) (describing the importance of the epidemiologic study); Reitze, supra note 244, at 186 (stating that plaintiffs prevailed in only $16 \%$ of contested cases).

248. 588 F. Supp. 247 (D. Utah 1984), rev'd, 816 F.2d 1417 (10th Cir. 1987). 
States government caused them to develop various types of cancers. ${ }^{249}$ After a non-jury trial, Judge Bruce Jenkins of the District of Utah had no trouble finding general causation. ${ }^{250}$ Specific causation, by contrast, presented the usual problems: how to prove that each plaintiff's disease resulted from radiation rather than other known or unknown causes, and if so, how to prove that the causal radiation came from the nuclear tests and not from other sources. ${ }^{251}$ Judge Jenkins formulated the problem in epidemiologic, risk-based terms and solved it by applying a "substantial factor" model of causation-in-fact for risk contribution, in lieu of but-for causation. ${ }^{252} \mathrm{He}$ considered but rejected equating proof of more than a doubling of risk with proof of substantial factor causation. ${ }^{253}$

Just four months after Judge Jenkins decided Allen, Judge Jack Weinstein of the Eastern District of New York elaborated on the doubling-plus rule. ${ }^{254}$ Judge Weinstein considered whether to approve a tentative settlement between a class of veterans alleging injuries from exposure to Agent Orange and "a major portion of the chemical industry." ${ }^{255}$ The compromise settlement was justified, Judge Weinstein concluded, by the litigation risks the class faced. ${ }^{256}$

Chief among those litigation risks was the difficulty of proving that exposure to Agent Orange caused any of the disparate injuries suffered by the class members. ${ }^{257}$ Judge Weinstein explained that the Agent Orange plaintiffs faced all three of the classic causal problems of toxic torts. ${ }^{258}$ First, based largely on epidemiologic evidence, the plaintiffs' claim of general causation was gravely in doubt. ${ }^{259}$ Second, all of the plaintiffs faced a version of the multiple-exposure problem, as it would be virtually impossible to establish which manufacturers'

249. See id. at 258 .

250. Id. at 405 (recognizing that there "appears to be no question whether or not ionizing radiation causes cancer and leukemia. It does.”); see id. at 258 (explaining that the judge acted as factfinder pursuant to 28 U.S.C. $\$ 2402$ (1976)).

251. Id. at 405-06.

252. Id. at 428 (holding that an inference of substantial factor causation may be drawn from evidence showing a significant increase in risk resulting from defendant's conduct).

253. Id. at 416-18. Judge Jenkins nevertheless made factual findings that closely, though not perfectly, tracked the results that would have followed application of the doubling-plus rule. See $i d$. at 429-40 (describing, for each plaintiff's claim, the evidence of increased risk and the court's factual finding).

254. In re "Agent Orange" Prod. Liab. Litig., 597 F. Supp. 740, 746 (E.D.N.Y. 1984), aff'd, 818 F.2d 145 (2d Cir. 1987).

255. Id.

256. Id. (holding that after "weighing the uncertainties and legal obstacles that would accompany years of protracted litigation were the case to go to trial, the court has concluded that the settlement should be approved."); $i d$. at 757 ("[Settlement] gives the class more than it would likely achieve by attempting to litigate to the death.").

257. Id. at 782 .

258. Id.

259. Id. at 782-95. 
products any service member was exposed to.$^{260}$ Third, even if the plaintiff class could overcome those two problems, specific causation remained a near insuperable obstacle under "traditional tort principles." ${ }^{261}$ Relying heavily on a then-recently published article by Professor David Rosenberg, ${ }^{262}$ Judge Weinstein explained the doubling-plus rule as comporting with a "weak" version of the preponderance standard, ${ }^{263}$ concluded that it would produce unjust and economically inefficient results in a mass exposure case, and advocated proportional recovery as a solution. ${ }^{264}$ Foreshadowing (at least in part) the problem that would complicate Bostic, Judge Weinstein also noted that the existence of multiple tortfeasors who exposed the plaintiff class to the same product exacerbated the problems of the doubling-plus rule by making it proportionately less likely that any one manufacturer's product caused an individual plaintiff's harm. ${ }^{265}$

In the 1990s, court opinions adopting some form of the doubling-plus rule proliferated. ${ }^{266}$ Bendectin was a major reason. ${ }^{267}$ And Bendectin produced

260. Id. at 819. Judge Weinstein assumed that some theory of burden shifting, alternative liability, or enterprise liability could overcome the "indeterminate defendant" problem. Id. at 81933.

261. Id. at 835 .

262. David Rosenberg, The Causal Connection in Mass Exposure Cases: A "Public Law" Vision of the Tort System, 97 HARV. L. REV. 849 (1984).

263. The "weak" and "strong" versions of the preponderance rule, in Rosenberg's language, differ in whether "particularistic" proof of specific causation is required in addition to proof of the magnitude of the relative risk. The strong version requires such proof; the weak version allows causation to be inferred based only on more than doubling of risk. See id. at 857-58.

264. In re "Agent Orange" Prod. Liab. Litig., 597 F. Supp. at 824.

265. Id. at 837. Judge Weinstein's hypothetical illustration implicitly assumed that the different defendants' products were competing causes and that all exposures were identical.

266. Carruth and Goldstein identified only two more opinions, after Agent Orange, that referred to the doubling-plus rule during the rest of the 1980s. See Carruth \& Goldstein, supra note 145, at 197-99, 199 n.9 (citing Manko v. United States, 636 F. Supp. 1419 (W.D. Mo. 1986), aff'd in relevant part, 830 F.2d 831 (8th Cir. 1987)). By contrast, they identified twenty-six such cases decided between 1990 and early 1999. Carruth \& Goldstein, supra note 145, at 197. I identified two additional opinions issued in the 1990s that at least obliquely discussed the doubling-plus rule. See Wade-Greaux v. Whitehall Labs., Inc., 874 F. Supp. 1441, 1452 (D. V.I. 1994) (equating relative risk greater than two with more than $50 \%$ probability of causation in an individual case, but not holding this was sufficient or required to satisfy the preponderance standard); Hand v. Norfolk So. Ry. Co., No. 03A01-9704CV-00123, 1998 WL 281946, at*3 (Tenn. App. 1998) (agreeing that doubling-plus is relevant, but rejecting defendant's argument that proof of relative risk greater than two is required as a matter of law).

267. Five of the cases Carruth and Goldstein identified were Bendectin cases. Carruth \& Goldstein, supra note 145, at 199 n.9. This was more than for any other substance except asbestos, $i d$., and of the nine asbestos decisions listed, four emerged from the same civil action. Id. at 197-99 (listing cases). It is noteworthy that the asbestos cases that elicited discussion of the doubling-plus rule did not involve asbestos's signature diseases, asbestosis and mesothelioma, or even lung 
Havner.

\section{B. Bendectin, Doubling-plus, and Havner: The Specific / General Causation Muddle}

The saga of the Bendectin cases has been amply and ably told elsewhere. ${ }^{268}$ The claims all eventually failed when, in the face of a large body of powerful epidemiologic studies that failed to detect any statistical association between Bendectin and any particular type of birth defect, the courts held plaintiffs' causation evidence inadmissible, insufficient as a matter of law, or both. ${ }^{269}$

What is pertinent here is how the doubling-plus rule crept into the courts' Bendectin decisions. The first appearance was in the 1990 DeLuca decision, ironically one of the few Bendectin appeals that a plaintiff won. ${ }^{270}$ The trial judge had excluded plaintiffs' proffered expert testimony on causation and granted summary judgment for the defendant. ${ }^{271}$ Ruling before the Supreme Court's Daubert decision, ${ }^{272}$ the Third Circuit reversed. ${ }^{273}$ In the course of explaining why it felt the testimony should have been admitted, the court correctly observed that a statistically significant relative risk greater than 1.0 could be part of the support for an inference of general causation. ${ }^{274}$ But in the course of inviting the defendant to renew its motion for summary judgment on remand, ${ }^{275}$ the court stated that even if plaintiffs' epidemiologic evidence were ultimately admissible, to be sufficient it must satisfy the doubling-plus rule:

If New Jersey law requires the DeLucas to show that it is more likely than not that Bendectin caused Amy DeLuca's birth defects, and they are forced to rely solely on ... . epidemiological analysis in order to avoid summary judgment, the relative risk of limb reduction defects ... will,

cancer, for which general causation by asbestos is widely accepted, but other cancers for which the general causation link to asbestos was disputed. Id. (listing opinions in cases involving claims for colon and larynx cancer allegedly caused by asbestos exposure).

268. See generally GREEN, supra note 124; SANDERS, supra note 122.

269. SANDERS, supra note 122, at 146-49 tbl. 14, 156-57 tbl. 15 (listing trial and appellate court decisions, respectively, in Bendectin cases); $i d$. at 190 (noting that the judiciary became convinced that any verdict for plaintiff was wrong).

270. DeLuca v. Merrell Dow Pharm., Inc., 911 F.2d 941, 959 (3d Cir. 1990).

271. Id. at 943 .

272. Daubert v. Merrell Dow Pharm., Inc., 509 U.S. 579 (1993) (establishing, in a Bendectin case, standards for the admissibility of scientific expert testimony).

273. Id.

274. DeLuca, 911 F.2d at 947-48; see also id. at 958 (explaining that scientifically reliable testimony that, for example, $25 \%$ of cases were "attributed to Bendectin exposure ... would be a basis from which a jury could rationally find that Bendectin could have caused" the plaintiff child's birth defects). The record in that case gave the court no occasion to discuss the factors epidemiologists consider in assessing whether an observed association demonstrates a causal relation.

275. Id. at 955 . 
at a minimum, have to exceed "2[.]"276

In this statement the Third Circuit shifted from discussing general causation to discussing specific causation. However, it did not make that shift explicit.

The Ninth Circuit, on remand from the Supreme Court in Daubert, picked up and ran with DeLuca's dictum. ${ }^{277}$ The Ninth Circuit had initially affirmed the district court's summary judgment based on a lack of any reliable evidence that Bendectin caused birth defects at all-that is, for failure to prove general causation. ${ }^{278}$ After the Supreme Court reversed and remanded for application of the new standard for admissibility of expert testimony, the doubling-plus rule provided the circuit court's rationale for upholding the summary judgment even if plaintiffs could raise a material dispute of fact against all of the negative epidemiologic evidence. ${ }^{279}$ The court noted that plaintiffs' experts "testif[ied] that Bendectin is a teratogen" based in part on "statistical studies [that] show that Bendectin use increases the risk of birth defects," but that "[n]one of plaintiffs" epidemiological experts claim[ed] that ingestion of Bendectin during pregnancy more than doubl[ed] the risk of birth defects." 280 The latter proof was necessary, the court reasoned, for plaintiffs to show that Bendectin "more likely than not caused their injuries." 281 Justifying the exclusion of the plaintiffs' testimony, the court held that epidemiologic studies showing elevated but less than doubled risk would confuse the jury: "[a] relative risk of less than two may suggest teratogenicity, but it actually tends to disprove legal causation. ..."282 The court unquestionably understood the difference between general and specific causation, but its distinction between "teratogenicity" and "legal causation" was unfortunately obscure for such a "high-profile" opinion. ${ }^{283}$

276. Id. at 958 (citing Manko v. United States, 636 F. Supp. 1419, 1434 (W.D. Mo. 1986) (applying the doubling-plus rule in a swine flu vaccine case), aff'd in part, 830 F.2d 831 (8th Cir. 1987)).

277. See Daubert v. Merrell Dow Pharm., Inc., 43 F.3d 1311 (9th Cir. 1995) (on remand).

278. Daubert v. Merrell Dow Pharm., Inc., 951 F.2d 1128, 1129 (9th Cir. 1991), vacated, 509 U.S. 579 (1993) (holding that testimony based on unpublished reanalyses of epidemiologic data was not admissible in light of "more than 30 published [epidemiologic] studies involving over 130,000 patients" none of which "had demonstrated a statistically significant association between Bendectin and birth defects").

279. Daubert, 43 F.3d at 1320 (on remand).

280. Id. at 1320-21 (citing DeLuca v. Merrell Dow Pharm., Inc., 911 F.2d 941, 959 (3d Cir. 1990)).

281. Id. at 1320. The court acknowledged that a relative risk of less than two might suffice if accompanied by evidence showing, for example, that a particular plaintiff was not exposed to other risk factors that had been identified by epidemiologic study.

282. Id. at 1321 .

283. Andrew Jurs, Judicial Analysis of Complex \& Cutting-Edge Science in the Daubert Era: Epidemiologic Risk Assessment as a Test Case for Reform Strategies, 42 ConN. L. REV. 49, 55 (2009). 
Havner, two years later, was the next major Bendectin decision. ${ }^{284}$ When the Havner court stated that plaintiffs could rely on epidemiology "in the absence of direct, scientifically reliable proof of causation," 285 it conflated the concepts of general and specific causation that it had distinguished one paragraph before. ${ }^{286}$ This conflation produced theoretical incoherence in the court's analysis as Havner proceeded to consider methodological issues in finding epidemiologic associations, statistical significance testing for Type I error in associations, criteria for determining whether an association is causal, external validity standards for inference from epidemiologic studies to individual plaintiffs, and the doubling-plus rule-all without ever making clear whether the legal significance of each issue applied to general or specific causation. And all of this discussion occurred in the context of a plaintiff's case that foundered on general causation, failing for a lack of evidence "that Bendectin causes birth defects in humans." 287

Perhaps as a result of this context, Havner repeatedly framed the doublingplus rule as relevant to the issue of general causation. ${ }^{288}$ Introducing its discussion of the rule, the court noted: "[t]he Havners rely to a considerable extent on epidemiological studies for proof of general causation. Accordingly, we consider the use of epidemiological studies and the 'more likely than not' burden of proof." ${ }^{289}$ In concluding that "there is a rational basis for relating the

284. See SANDERS, supra note 122, at 146-49, 157-59 (listing trial and appellate court decisions in Bendectin cases in chronological order). The only appellate court decision listed between the Daubert remand decision and Havner, Raynor v. Merrell Pharmaceuticals, Inc., 104 F.3d 1371 (D.C. Cir. 1997), simply applied the Supreme Court's Daubert decision and existing circuit precedent on the admissibility of plaintiffs' expert testimony.

285. Merrell Dow Pharm., Inc. v. Havner, 953 S.W.2d 706, 715 (Tex. 1997).

286. See id. at 714 (defining general and specific causation); id. at 714-15 (stating that in some cases "controlled scientific experiments" can determine general causation and "objective criteria" can determine specific causation).

287. Id. at 730 (rejecting testimony of one plaintiffs' expert who relied on animal in vitro studies); see also id. at 729 (rejecting testimony of another plaintiffs' expert who relied on animal studies because of doubts about extrapolation to humans in light of large body of negative epidemiologic results). The court reached a similar conclusion with respect to the testimony of each of plaintiffs' experts who relied on epidemiologic studies. See id. at 725 (rejecting testimony of one plaintiffs' expert who relied on epidemiology because studies did not show statistically significant association between Bendectin and limb reductions); $i d$. at 726-27 (rejecting testimony of another plaintiffs' expert who relied on epidemiology because of a large body of negative epidemiologic results and lack of publication and replication); id. at 730 (rejecting testimony of the plaintiffs' expert who opined on specific causation because opinion was based on epidemiologic studies that did not find general causation). Joseph Sanders identified the reasons for defendant's win in Havner as "the [f] ailure to prove general causation with a preponderance of the evidence" and the "[f]ailure to present any qualified expert at trial on the general causation question"). SANDERS, supra note 122 , at 158 .

288. Havner, 953 S.W.2d at 715.

289. Id. (emphasis added). 
requirement that there be more than a 'doubling of the risk' to our no evidence standard of review and to the more likely than not burden of proof," 290 the court simply referred to "causation." ${ }^{291}$ It next explained the doubling-plus logic with an example that seemed to refer to specific causation, ${ }^{292}$ but then immediately summed up: "[ $\mathrm{t}]$ his is an oversimplification of statistical evidence relating to general causation ... but it illustrates the thinking behind the doubling of the risk requirement." 293

The "thinking behind the doubling of the risk requirement," however, has nothing whatever to do with "statistical evidence relating to general causation." The doubling-plus rule depends on a presumed congruence between greater than $50 \%$ attributable fraction in a population sample and more likely than not causation in an individual case. ${ }^{294}$ For courts and commentators that accept it, doubling-plus provides a technique, a theoretical justification, and a substantive standard for making an inference from group-based studies supporting general causation to the otherwise irresolvable question of specific causation.

Havner reasoned about specific causation while talking about general causation. ${ }^{295}$ Small wonder, then, that Russelyn Carruth and Bernard Goldstein

290. Id. at 717 .

291. Id.

292. Id. (describing a hypothetical in which more than doubling of the risk means "it may be statistically more likely than not that a given individual's disease was caused by" exposure) (first emphasis in original, second emphasis added).

293. Id. (emphasis added). The court continued to describe two commentators' argument that (in the court's words) "the probability of general causation changes as the level of statistical significance changes," so a relative risk of 2.75 could result in as little as $43 \%$ or $52 \%$ probability of "general causation" depending on the significance level chosen. Id. at 718.

294. Id. at 715 .

295. The way in which Havner linked doubling-plus and general causation must be distinguished from a different argument sometimes made about the probative value of relatively small relative risk values. Strength of association is one of the criteria epidemiologists consider in assessing whether an observed association is causal. Hill, supra note 129, at 295. Methodological difficulties—bias, confounding, and individual variability in exposures and susceptibility-can make it difficult for observational epidemiologic studies reliably to detect and assess the causal significance of small measured increases in relative risk. See Michael D. Green, The Future of Proportional Liability: The Lessons of Toxic Substances Causation, in EXPLORING TORT LAW 352, 357-70 (M. Stuart Madden ed., 2005); As a result, "[m]any scientists are leery of accepting a group study that finds an increased incidence of disease below a certain magnitude as demonstrating a true causal relationship.” Restatement (ThIRD) OF TORTS: LiAB. FOR PHYSiCAL \& EMOTIONAL HARM $\S 28 \mathrm{cmt}$ c. reporters' note (2010). These arguments are purely about whether general causation can be inferred from epidemiologic results. They have nothing to do with specific causation. In connection with general causation, the relative risk 2.0 threshold can have no magical meaning. A small, methodologically challenged study with a statistically significant relative risk greater than 2.0 might provide relatively weak evidence of general causation. A large, powerful, well-designed, and well-controlled study with high-quality data (perhaps a randomized clinical trial or an observational study that does a good job accounting for possible confounders) might provide very 
assessed Havner's meaning as "unclear." 296 As Havner settled into its "foundational" place in Texas toxic tort law, ${ }^{297}$ its lack of clarity began to have consequences.

\section{From Havner Through Flores and Garza to Bostic: Further Muddying the Muddle}

Lower Texas state courts and federal courts applying Texas law naturally began to follow Havner. ${ }^{298}$ Unsurprisingly, the doubling-plus rule appeared in toxic tort cases involving substances other than Bendectin. ${ }^{299}$ Courts sometimes disagreed about how literally Havner's requirements, including the doubling-plus requirement, should be interpreted. ${ }^{300}$

strong evidence of a causal association that less than doubles the risk. Havner itself made these points, but only after it announced the doubling-plus rule and then retreated from holding that a showing of more than doubled relative risk is alone sufficient for a plaintiff to reach a jury. See Havner, 953 S.W.2d at 718 ("We do not hold . . that a relative risk of more than 2.0 is a litmus test or that a single epidemiological test is legally sufficient evidence of causation."); id. at 719 (" $[\mathrm{S}]$ ome of the literature indicates that epidemiologists consider a relative risk of less than three to indicate a weak association"). As Havner's example shows, this argument is utterly unmoored from the supposed "rational connection" between a relative risk greater than 2.0 and the more likely than not preponderance of the evidence standard.

296. Carruth \& Goldstein, supra note 145, at $204 \&$ n.32; see also Tumlinson v. Advanced Micro Devices, Inc., No. 08C-07-106, 2013 WL 7084888, at *5 (Del. Super. Oct. 15, 2013) (noting that Havner's "analysis muddles general and specific causation"), aff' $d$, 81 A.3d 1264 (Del. 2013).

297. Bostic, 439 S.W.3d at 347 ("Havner is a foundational part of our jurisprudence.").

298. See, e.g., Cano v. Everest Minerals Corp., 362 F. Supp. 2d 814 (W.D. Tex. 2005).

299. See id. at 822 ("Although Havner was a Bendectin case, the Court spoke generally about the use of epidemiological evidence . . . and the Court does not read the opinion to limit those principles solely to the Bendectin context.”); Matt Dietz \& Co. v. Torres, 198 S.W.3d 798, 804 (Tex. App. 2006) (holding plaintiff failed to satisfy Havner requirements in claim that pesticide exposure caused laryngeal cancer); Daniels v. Lyondell-Citgo Refining Co., 99 S.W.3d 722 (Tex. App. 2003); see also cases cited infra note 308.

300. Compare, e.g., Exxon Corp. v. Makofski, 116 S.W.3d 176, 182-83, 188 (Tex. App. 2003) (stating that relative risk greater than two is required after Havner); Wells v. SmithKline Beecham Corp., No. A-06-CA-126-LY, 2009 WL 564303, at *8 (W.D. Tex. Feb. 19, 2009) (concluding that "Havner establishes substantive Texas law on a plaintiff's causation burden of proof"; finding proffered testimony insufficient); Daniels, 99 S.W.3d at 728-29 (rejecting testimony that was based on several studies reporting relative risks greater than 1.0 but less than 2.0), with, e.g., Cotroneo v. Shaw Envtl. \& Infrastructure, Inc., No. H-05-1250, 2007 WL 3145791, at *3 n.5 (S.D. Tex. 2007) (stating that Havner "hedges this [doubling-plus] requirement with qualifiers"), aff'd in part, vacated in part on other grounds, 639 F.3d 186 (5th Cir. 2011); Merck \& Co. v. Garza, 277 S.W.3d 430, 435 (Tex. App. 2008) (stating that Havner did not establish a bright-line rule requiring relative risk greater than two), rev'd, 347 S.W.3d 256 (Tex. 2011); Minn. Mining \& Mfg. Co. v. Atterbury, 978 S.W.2d 183, 198 (Tex. App. 1998) (interpreting Havner to allow proof of relative risks less 
The decisions also reflected confusion about whether Havner's doubling-plus rule fit in the analysis of general causation or specific causation, which was also unsurprising in light of the confusion evident in Havner itself. Some courts saw through Havner's language and considered the doubling-plus rule in evaluating a plaintiff's proof of specific causation. ${ }^{301}$ More often, however, courts followed Havner's structure and identified a statistically significant association showing more than a doubling of risk as essential for an epidemiologic study to provide any evidence of general causation. ${ }^{302}$ At least one court conflated statistical significance and the doubling-plus rule. ${ }^{303}$

A decade passed between Havner and Flores,${ }^{304}$ the Supreme Court of Texas's next significant ruling on toxic tort causation. Flores, an auto mechanic, alleged that he developed asbestosis as a result of exposure to asbestos during thousands of brake installation and repair jobs. ${ }^{305}$ Borg-Warner, the only nonsettling defendant, manufactured the brakes used in just a fraction of those jobs. ${ }^{306}$

Like Bostic which was to follow, Flores involved asbestos exposures much smaller than in many occupations. ${ }^{307}$ Yet because Mr. Flores suffered from asbestosis, ${ }^{308}$ " $t$ there was no question concerning the sufficiency of the plaintiff's

than 2.0 to suffice if "supported by other credible, reliable evidence").

301. See, e.g., In re Asbestos Prod. Liab. Litig. (No. VI), No. MDL-875, 2012 WL 760739 (E.D. Pa. Feb. 17, 2012). For a court that got this right even after Bostic, see Sedgwick v. BP Products Northern America, Inc., No. G-13-188, 2014 WL 6911543, at*3 (S.D. Tex. Nov. 4, 2014).

302. E.g., Lofton v. McNeil Consumer \& Specialty Pharm., 682 F. Supp. 2d 662, 668 (N.D. Tex. 2010) (listing relative risk greater than two and statistical significance at $95 \%$ level as requirements epidemiologic studies must meet to establish some evidence of general causation); Wells, 2009 WL 564303, at *11 (stating that even a study compliant with Havner's doubling-plus rule could not establish general causation under Havner because no other study satisfied the rule); Burton v. Wyeth-Ayerst Labs., 513 F. Supp. 2 d 719, 730 (N.D. Tex. 2007) (same as Lofton); Faust v. BNSF Ry. Co., 337 S.W.3d 325, 337 (Tex. App. 2011) (same); Matt Dietz, 198 S.W.3d at 805 (holding plaintiff failed to satisfy Havner requirements in claim that pesticide exposure caused laryngeal cancer).

303. Daniels, 99 S.W.3d at 730 ("None of the studies [relied on by plaintiffs' experts] has the Havner requisite risk-doubling; therefore, none of the studies reaches the Havner standard of statistical significance. The Daniels family presented no evidence of general causation.").

304. Borg-Warner Corp. v. Flores, 232 S.W.3d 765 (Tex. 2007).

305. Flores testified he did roughly twenty brake jobs per week during a thirty-five year career. $I d$. at 866. Assuming these figures are accurate and Flores worked fifty work weeks per year, the total number of brake jobs would have been approximately 35,000 .

306. Flores testified that five to seven of each week's jobs involved Borg-Warner brakes. Id. This works out to a total of approximately 8,750 to 12,250 jobs that would have involved BorgWarner brakes.

307. Id. at 774 .

308. At trial, the defendant contended otherwise. A defense expert testified that Mr. Flores did not have asbestosis but rather another form of interstitial lung disease. $I d$. at 768 . The evidence 
total dose, only the dose received from Borg-Warner." ${ }^{309}$ The Supreme Court of Texas held the plaintiff's proof of the amount of his exposure to asbestos from Borg-Warner's brake pads was insufficient to support a "substantial factor" finding. ${ }^{310}$ Yet even in Flores, where the general causal link between plaintiff's asbestosis and his aggregate exposure to asbestos seemed apparent, questions of general causation troubled the court. ${ }^{311}$ The court noted evidence that asbestosis generally resulted either from long-term heavy asbestos exposure or from shortterm but extremely heavy exposure. ${ }^{312}$ Because Flores did not quantify the aggregate dose of exposure he received from his brake work, the court reasoned, "the jury could not evaluate the quantity of respirable asbestos to which Flores might have been exposed or whether those amounts were sufficient to cause asbestosis"- a question of general causation. ${ }^{313}$ In that context, the court invoked Havner's doubling-plus rule: "There were no epidemiological studies showing that brake mechanics face at least a doubled risk of asbestosis," the court observed. ${ }^{314}$

Four years later, the Supreme Court of Texas decided Merck \& Co. v. Garza and locked in its view that doubling-plus is a matter of general causation. ${ }^{315}$ The Garza plaintiffs alleged that the prescription drug Vioxx caused Leonel Garza's fatal heart attack. ${ }^{316}$ The plaintiffs relied on more than one clinical trial, as well as a meta-analysis of multiple trials, with statistically significant results showing that Vioxx more than doubled the risk of heart attacks. ${ }^{317}$

There may have been plenty of reason to question specific causation in Garza, particularly under the but-for test. Leonel Garza had pre-existing heart disease that a jury could easily have viewed as a competing cause, ${ }^{318}$ although a finding of concurrent contributing causation by Vioxx would not necessarily

showed that smoking can also cause interstitial lung disease, $i d$. at 766, and that Flores had smoked for many years, $i d$. at 768 . Thus, the trial record at least suggested the possibility of a competing cause that explained the plaintiff's symptoms. Although the Supreme Court of Texas did not rely on that competing cause in reaching its decision, the possibility of causation by smoking may have encouraged the court to set a high bar for proof of exposure to Borg-Warner's asbestos.

309. Sanders, supra note 11 , at 1168.

310. Flores, 232 S.W.3d at 771-72 (holding plaintiff's evidence insufficient because the record "reveals nothing about how much asbestos Flores might have inhaled" nor about "what percentage of that indeterminate amount may have originated in Borg-Warner products").

311. Id.

312. Id. at 771 .

313. Id. at 771-72 (emphasis added).

314. Id. at 772 (footnote omitted). The court acknowledged that "such studies are not necessary to prove causation," but emphasized again that the doubling-plus rule "strikes a balance" in toxic tort cases. Id. (quoting Merrell Dow Pharm., Inc. v. Havner, 953 S.W.2d 706, 715 (Tex. 1997)).

315. 347 S.W.3d 256 (Tex. 2011).

316. Id. at 259-60.

317. Id. at 266-67.

318. The court related Garza's "long history of heart disease" at length. Id. at 259-60. 
have been absurd. ${ }^{319}$ Faced with a jury verdict in Garza's favor, however, the Supreme Court of Texas unanimously held that "the Garzas did not present reliable evidence of general causation" ${ }^{320}$ because they did not present more than one study showing a statistically significant relative risk greater than two in subjects who took Vioxx doses smaller than or equal to the dose Garza consumed. ${ }^{321}$

The general causation framing did not appear inadvertent. The Garza court carefully defined general causation as "whether a substance is capable of causing a particular injury or condition in the general population" 322 before stating that "Havner holds, and we reiterate, that when parties attempt to prove general causation using epidemiological evidence, a threshold requirement of reliability is that the evidence demonstrate a statistically significant doubling of the risk." ${ }^{323}$ As the authors of one treatise stated: "This cannot be correct." ${ }^{324}$ And yet it was repeated in Bostic. ${ }^{325}$

\section{Bostic: Confusion Reigns}

One might argue that if a court will insist on epidemiologic proof of an increased risk greater than two to prove causation in a toxic tort case, it does not much matter whether the court labels that a general causation requirement, a specific causation requirement, or neither. But it does matter. First, it matters because judicial decision-making should be coherent and the doubling-plus rule, if it makes sense at all, makes sense only in the context of specific causation. Second, it matters because confusion about the role of doubling-plus facilitated the shifts in causal models that led to the internally inconsistent holdings of Bostic. ${ }^{326}$ Third, it matters because courts that treat doubling-plus as a matter of general causation inevitably founder as they try to articulate the meaning of specific causation - and as they try to understand general causation as well.

The majority in Bostic addressed the disconnect between Havner, a case that turned on general causation, and Bostic, a case in which general causation was

319. Merck's studies of Vioxx revealed a higher incidence of adverse cardiovascular events "in patients with and without a history of atherosclerotic cardiovascular disease." McDarby v. Merck \& Co., 949 A.2d 223, 234 (N.J. Super. 2008). Thus, a jury might have chosen between two possible findings: (1) that Garza would have had his heart attack when he did even had he not taken Vioxx or (2) that but for the Vioxx (either acting alone or in combination with the heart disease), Garza's heart attack would not have occurred (at least when it did).

320. Garza, 347 S.W.3d at 268 (emphasis added).

321. Id. at 266-67 (discussing studies upon which plaintiffs' experts relied).

322. Id. at 262 (quoting Merrell Dow Pharm., Inc. v. Havner, 953 S.W.2d 706, 714 (Tex. 1997)).

323. Id. at 265.

324. David L. Faigman et AL., 3 Modern Sci. Evid. § 23:27 (2014-15 ed. 2014).

325. See Bostic v. Georgia-Pacific Corp., 439 S.W.3d 332, 349 \& n.74 (Tex. 2014) (quoting Havner, 953 S.W.2d at 715-18); see also id. at 362 (Guzman, J., concurring) (nothing that after Havner, plaintiffs show general causation by satisfying the doubling-plus rule).

326. See supra Part II.B. 
conceded, ${ }^{327}$ this way:

Havner was also concerned with specific causation. General causation is never the ultimate issue of causation tried to the finder of fact in a toxic tort case. The ultimate issue is always specific causation-whether the defendant's product caused the plaintiff's injury ... . In Havner, we held that where direct evidence of specific causation is unavailable, specific causation may be established through an alternative two-step process whereby the plaintiff establishes general causation through reliable studies, and then demonstrates that his circumstances are similar to the subjects of the studies. ${ }^{328}$

This bifurcation of Havner mimicked the United States Supreme Court's separation of "reliability" and "fit" as criteria for admissibility of expert testimony, ${ }^{329}$ but treated it as the boundary between general and specific causation. On its own terms, the Bostic court's description of Havner unquestionably included the doubling-plus rule as one of Havner's criteria for "reliable studies." ${ }^{330}$ Even the concurring and dissenting justices-who rejected the majority's requirement of a larger than doubling dose from each defendant's product-explicitly adopted the view that under Havner doubling-plus is required for proof of general causation. ${ }^{331}$ All nine justices agreed that when a

327. Bostic, 439 S.W.3d at 348 ("To some extent Havner's discussion of the use of scientific studies addressed whether those studies supported general causation-the issue of whether Bendectin was capable of causing birth defects."); id. ("In today's case, general causation is not an issue. Georgia-Pacific does not dispute, for purposes of this appeal, that exposure to asbestos fibers can cause mesothelioma."); id. at 351 (“As noted above, Havner was concerned with general causation while today's case is not.").

328. Id. at 351 .

329. See Daubert v. Merrell Dow Pharm., Inc., 509 U.S. 579, 590-91 (1993) (describing reliability and fit).

330. See Havner, 953 S.W.2d at 717-18 (adopting the doubling-plus rule as rationally connected to the preponderance standard); $i d$. at 718-19 (stating that even epidemiologic studies showing more than doubling of risk might not be considered "reliable" proof); id. at 721-24 (establishing statistical significance standards for reliable studies); $i d$. at 720-21 (holding that to survive legal sufficiency review a plaintiff must "do more" than produce epidemiology showing relative risk greater than two, by proving that plaintiff is similar to those in the study as well as ruling out plausible alternative causes). Like much else in Havner, the line between reliability and sufficiency of scientific proof of causation is at times blurry. Havner framed the requirement to show similarity between the plaintiff and the study subjects as a matter of sufficiency (presumably after scientifically reliable epidemiology had been introduced), but immediately afterward concluded "we emphasize that courts must make a determination of reliability from all the evidence." Id. at 720 (emphasis added).

331. Bostic, 439 S.W.3d at 362 (Guzman, J., concurring) (stating that a plaintiff using epidemiologic studies must show exposure to a dose that more than doubles risk to prove general causation); id at 370 (explaining that Havner held that when epidemiology shows that risk is more than doubled in a population exposed to a certain dose of a toxin, "those studies satisfy the demands 
plaintiff relies on epidemiologic proof of causation-and can get over the doubling-plus and other "reliability" hurdles listed in Havner - then proof of the plaintiff's similarity to the study subjects constitutes proof of specific causation. $^{332}$

On its face, this formulation might appear to adopt the "weak" version of the preponderance rule, freeing plaintiffs who can satisfy the doubling-plus requirement from the almost always impossible-to-satisfy demand that they produce particularistic evidence in support of their claims. ${ }^{333}$ The strictness of the similarity requirement as applied, however, undermines the notion that the Texas version of doubling-plus conceded much to the scientific indeterminacy of specific causation.

To prove similarity, Havner required a plaintiff to "show that he or she ... was exposed to the same substance . . . [at] exposure or dose levels . . . comparable to or greater than those in the studies." ${ }^{334}$ Given disease latency and the observational and often retrospective nature of epidemiologic investigation, proving the exposure levels of either the plaintiff or the study subjects is apt to be difficult. ${ }^{335}$ But even assuming exposure levels could be compared, the Havner

of ... general causation").

332. Id. at 351 (describing proof of similarity as the second step in a two-step process in which the first step is to establish general causation by epidemiologic studies that satisfy the doubling-plus rule and other requirements); id. at 362 (Guzman, J., concurring) ("In the wake of Havner and Flores," a plaintiff must show "that the plaintiff's exposure to the defendant's toxin was comparable to or greater than the more than doubling of the risk dose in the studies (specific causation)."); id. at 371 (Lehrmann, J., dissenting) ("With respect to ... specific causation, we held that ... [t]he claimant must ... show "that he or she is similar to those in the studies."') (quoting Havner, 953 S.W.2d at 720).

333. At least one lower Texas court seems to have understood Havner this way. Coastal Tankships, U.S.A., Inc. v. Anderson, 87 S.W.3d 591, 602 n.21 (Tex. App. 2002) (plaintiff can "prove specific causation circumstantially by taking general-causation evidence, such as epidemiological studies, and showing he is similar to the studies' subjects," thus allowing the same evidence to prove both general and specific causation). Another understood that the logic of doubling-plus inherently applies to specific causation. Mo. Pac. R.R. Co. v. Navarro, 90 S.W.3d 747, 758 (Tex. App. 2002) ("Specific causation is generally shown by a doubling of the risk factor."). More typically, however, lower Texas courts expressed the Havner distinction between general and specific causation in the same terms the Supreme Court of Texas adopted in Bostic. E.g., Lofton v. McNeil Consumer \& Specialty Pharm., 682 F. Supp. 2d 662, 668 (W.D. Tex. 2010) (listing doubling-plus as component of general causation); Faust v. BNSF Ry. Co., 337 S.W.3d 325, 337 (Tex. App. 2011) (same); Matt Dietz Co. v. Torres, 198 S.W.3d 798, 804 (Tex. App. 2006) (holding that plaintiff failed to prove general causation where the only epidemiologic study reported a relative risk of 1.5 and failed to prove specific causation by not establishing his similarity to the study subjects).

334. Havner, 953 S.W.2d at 720.

335. See Holcomb v. Georgia Pac., LLC, 289 P.3d 188, 195 (Nev. 2012) (concluding that Flores "swings too far" in favor of defendants because of the difficulty of quantifying defendantspecific and cumulative doses). 
rule eliminates any possibility of inference to lower doses, regardless of evidence of dose-response relationship. To take an oversimplified example, imagine that two studies of a substance measure a relative risk of 8.0 at dose $X$ and a relative risk of 1.0 at dose $X / 4$. What if the evidence shows a plaintiff received dose $X / 2$ ? In some cases any expert's attempt to interpolate and testify that the plaintiff received more than a doubling dose might be scientifically unreliable, but in other cases that interpolation might be widely accepted by scientists - or at least be subject to legitimate scientific disagreement. ${ }^{336}$ Havner decreed such interpolation impermissible - and testimony based on it both inadmissible and insufficient—as a matter of law. ${ }^{337}$

The majority in Bostic extended the rigidity of the similarity requirement by applying it to each source of asbestos individually. ${ }^{338}$ To some extent this would seem to follow from the majority's defendant-specific doubling-plus rule, but not entirely: one could imagine an expert testifying that a smaller exposure doubled the risk based on inference from studies of larger exposures associated with more-than-doubled relative risks. ${ }^{339}$ However, the Bostic majority left no ambiguity about how it would apply its so-called specific causation test of similarity:

So far as we can tell, none of the peer-reviewed scientific studies on which Plaintiffs' experts relied found a statistically significant link between mesothelioma and occasional exposure to joint compounds comparable to Bostic's exposure, namely the occasional exposure of a son helping his father on building renovation projects that were not the primary occupation of either father or son, and which included drywall work as well as other construction activities. ${ }^{340}$

To state the requirement in these terms is to explain why no one has studied such a meticulously constructed sample, ${ }^{341}$ notwithstanding the majority's sanctimonious observations about how thoroughly the health effects of asbestos

336. See Carruth \& Goldstein, supra note 145, at 209 (describing how dose-response effect could affect attempts to apply the doubling-plus rule). For illustrative purposes, the example considers only the point estimates of relative risk and takes no account of statistical confidence intervals.

337. Havner, 953 S.W.2d at 720. Garza reiterated this view. Merck \& Co. v. Garza, 347 S.W.3d 256, 266-67 (Tex. 2011).

338. Bostic v. Georgia-Pacific Corp., 439 S.W.3d 332, 358 (Tex. 2014).

339. A defendant would surely argue that such testimony should be excluded because the inference is "unreliable." Failing exclusion, a defendant would surely argue to the fact-finder that the inference should not be believed. The merits of either argument should depend on the facts of particular cases; debating those merits is beyond the scope of this Article. The important point here is that no reason exists to believe that it is in every case impossible to make a scientifically reliable inference of this sort.

340. Bostic, 439 S.W.3d at 358.

341. See id. at 364-65 (Guzman, J., concurring) ("As a practical matter, requiring this level of exactitude may imply that hardly any mesothelioma plaintiff can recover."). 
have been researched. ${ }^{342}$ Moreover, if mesothelioma risk is a function of cumulative dose, the majority's desired study is not even biologically meaningful to Bostic's case. The majority's view was too much for Justice Guzman, whose concurring opinion argued that dose-response extrapolation should be permitted as a matter of law but was not, as a matter of fact, supported by reliable evidence in Bostic. ${ }^{343}$ Justice Guzman's view has merit, but it is still mistaken in tying even an extrapolated doubling dose to general causation. ${ }^{344}$

The Bostic-Havner rigid requirement of similarity between plaintiffs and study subjects also denies courts the ability to consider individual characteristics of a plaintiff that might support a finding of specific causation. For example, in studies of occupational exposures, the exposed study subjects are typically adults. However, Bostic's exposure to asbestos from Georgia-Pacific's joint

342. See id. at 350 (noting that plaintiffs' witness testified that statistical association between asbestos exposure and mesothelioma was documented by 1963 and by 1965 over one thousand publications discussed asbestos disease). The epidemiologic study the court imagined would require comparison of a sample of people whose only known non-background exposure was as described to a sample of people with no non-background exposure. A moment's reflection conjures the methodological problems any such study would face in identifying the exposures of potential subjects in either category. It is also easy to imagine that even if such a study could be conducted, the "exposed" sample inevitably would include a range of actual exposures, some of which would likely exceed the exposures of any particular plaintiff, and thus would still be subject to a "similarity" challenge under the court's standards. These methodological issues are not answered by the Bostic majority's assurance that "the more toxic the substance, the easier it should be to establish a Havner-compliant statistical link." Id. at 358. See generally Goldstein, supra note 151, at 572-77 (exploring problems that arise because the exposed group in any epidemiologic study generally has experienced heterogeneous exposures).

343. Bostic, 439 S.W.3d at 361-64 (Guzman, J. concurring) (noting that lack of a scientific basis for extrapolation left an analytical gap and therefore plaintiffs had no evidence of causation under Texas law). The plaintiffs' experts based their opinions in part on a government document making risk calculations based on extrapolations from a published dose-response model. Id. Justice Guzman, however, would have required the plaintiffs to introduce not just the government document but the underlying scientific literature on which it was based. Id. at 364 .

344. Even the dissent embraced the view that plaintiffs who rely on epidemiologic proof must, per Havner, produce evidence of doubling of the risk to prove general causation. Id. at 376 (Lehrmann, J., dissenting). However, the dissent's analysis evaded this requirement by arguing that the Bostic plaintiffs established both general and specific causation through "direct" scientific proof, in contrast to the epidemiologic "alternative" authorized by Havner. Id. The dissent recapitulated testimony about "the biological process by which asbestos fibers migrate through the lung, into the pleura, and cause genetic errors in mesothelial cells" that could arguably be considered "direct" evidence of general causation. Id. at 367-68, 376. However, the "direct" evidence of specific causation the dissent cited was mostly about Bostic's individual exposure levels. $I d$. at 377 . The dissenters were willing to accept relatively qualitative evidence of exposure (unlike the majority, which demanded quantitative evidence of exposure greater than a proven, quantified risk-doubling exposure level). $I d$. at 379. But all three opinions in Bostic focused on evidence of exposure as proof of specific causation. 
compound occurred when Bostic was a child. ${ }^{345}$ The Bostic majority acknowledged that "several experts agreed that children are especially vulnerable to exposure to asbestos and carcinogens in general" ${ }^{346}$ and did not suggest that any expert disputed this. Given that a childhood exposure creates more risk than a similar exposure during adulthood, one would expect a plaintiff and a defendant vigorously to contest the extent to which proof of a childhood exposure provides additional support for an inference of specific causation. ${ }^{347}$ However, the Bostic majority's opinion entirely precluded that debate. ${ }^{348}$ Under the Bostic majority's reasoning, the childhood timing of an exposure can have no significance at all — unless the plaintiff finds an epidemiologic study showing more than a doubling of risk among children exposed to an equal or smaller dose as the plaintiff's dose. ${ }^{349}$

\section{E. Judges Reading Scholars and Vice Versa: A Failure to Communicate}

Judges and other observers often lament that contemporary legal scholarship lacks relevance to the daily work of resolving legal disputes. ${ }^{350}$ However, toxic tort causation, while of great academic and philosophical interest, is also vitally important to litigants, trial judges, and appellate judges in countless cases. The topic therefore presents an excellent opportunity for academic commentators to

345. Id. at 353. The majority did not hold that plaintiffs failed to prove that Bostic was exposed to Georgia-Pacific products, but rather that plaintiffs failed to quantify that exposure and compare it to a doubling dose. $I d$.

346. Id.

347. The court noted that plaintiffs described Bostic's childhood exposure as "particularly significant." $I d$.

348. Id.

349. Similarly, the logic of Bostic would preclude consideration of other factors, such as genetic susceptibility to carcinogens, that might support an inference that an individual experienced a greater risk increment from a given exposure than did the "average" study subject. By contrast, Bostic (following Havner), requires plaintiffs to rule out other risk factors that might support an inference that an individual experienced a smaller risk increment from an individual exposure than did the "average" study subject. Other courts that have adopted the doubling-plus rule have done so in a similarly asymmetrical way. See, e.g., Estate of George v. Vt. League of Cities \& Towns, 993 A.2d 367, 384 (Vt. 2010) (Reiber, C.J., dissenting) (arguing that the trial judge sitting as the factfinder should have considered plaintiff's evidence that he may have faced greater risks than the average study subject rather than relying on fact that the average relative risk in several epidemiologic studies was less than two).

350. E.g., Adam Liptak, The Lackluster Reviews That Lawyers Love to Hate, N.Y. TIMES, Oct. 22, 2013, at A15, available at http://www.nytimes.com/2013/10/22/us/law-scholarships-lacklusterreviews.html?_r=0 [http://perma.cc/KKP6-TY6N] (quoting Second Circuit Judge Dennis G. Jacobs: "I haven't opened up a law review in years"); Leonard Hoffman, Lord Hoffman, Causation, in Perspectives on CAusation, 3, 3 (Richard Goldberg ed., 2011) (noting that in British courts, causation doctrine is a notable exception to the trend of courts citing academic work more often, and concluding that either judges or scholars "must be missing something"). 
engage with the courts that craft evolving common-law doctrine and vice versa. ${ }^{351}$

Meaningful engagement requires careful reading and understanding on both sides of the dialogue. Unfortunately, the evolution of the doubling-plus rule-from its origins through its adoption by the Supreme Court of Texas in Havner and its subsequent articulations by that court-suggests that judges and scholars have sometimes failed to receive each other's meaning.

The earliest articulation of the doubling-plus rule that I have been able to find is in a 1960 article by Samuel Estep. ${ }^{352}$ Early in the atomic age, Estep considered the problem of radiation-induced disease and anticipated many problems that would come to prominence in future toxic tort cases. ${ }^{353}$ Noting the impossibility of proving "the biological connection of irradiation with a particular nonspecific, latent injury under existing [tort] rules," Estep argued that the doublingplus rule was the only approach to such cases concordant with proof of but-for causation under the preponderance of the evidence standard. ${ }^{354}$ Estep clearly understood the doubling-plus rule as a response-albeit one he considered inadequate 355 - to the problem that has since become known as "specific causation." 356

However, the type of toxic tort litigation Estep anticipated did not become common until the 1980s and it mostly did not involve claims of radiation-induced illness. ${ }^{357}$ The first judicial adoptions of the doubling-plus rule, in the early swine flu vaccine cases, did not cite Estep's article or any other legal scholarship. ${ }^{358}$

351. The bar seems to understand this: a fair amount of the recent law review literature on toxic tort causation in general, and mesothelioma cases in particular, has been authored by practicing attorneys whose clients have dogs in the fight. E.g. Richard O. Faulk, Dispelling the Myths of Asbestos Litigation: Solutions for Common Law Courts, 44 S. TEX. L. REv. 945 (2003) (defense attorney favorably describing Havner); Andrew S. Lipton, Proving Toxic Harm: Getting Past Slice and Dice Tactics, 45 McGeorge L. Rev. 707 (2014) (plaintiffs' attorney criticizing doubling-plus rule).

352. Samuel D. Estep, Radiation Injuries and Statistics: The Need for a New Approach to Injury Litigation, 59 MicH. L. REV. 259 (1960). I am indebted to Michael Green, who first called my attention to this article.

353. For example, Estep anticipated the need to reform statutes of limitations to take into account long disease latency periods. See id. at 262.

354. Id. at 274.

355. Using radiation-induced leukemia as an example, Estep argued that the doubling-plus rule would lead to undercompensation for claims that had to be brought after exposure but before disease manifestation and to overcompensation for claims that could be brought after manifestation. $I d$. at 275-80. He proposed creating a fund upon exposure that would be used to compensate those who developed disease in the future. Id. at 281-88.

356. Id. at 279 ("Proof still is purely statistical in nature; . . assignment of natural and radiation causes to specific cases is impossible.").

357. The notable radiation case in the 1980s involved claims by persons exposed during nuclear weapons tests. Allen v. United States, 588 F. Supp. 247 (D. Utah 1984). See supra text accompanying notes 248-53.

358. See supra text accompanying notes 240-43. 
Soon, however, the law reviews began to fill with discussions of how epidemiologic results might bear on general and specific causation, some of which rehearsed Estep's concerns about the doubling-plus rule. ${ }^{359}$

By the time the Supreme Court of Texas decided Havner in 1997, a significant body of literature as well as a significant body of case law had built up. The terms general causation and specific causation had become widely used; the Havner court adopted them and defined them in the conventional way before addressing the role of epidemiology in proving causation. ${ }^{360}$ The Havner court then embarked on an unusually wide-ranging discussion of both the case law and the literature. ${ }^{361}$ Unfortunately, that discussion blurred the difference between two distinct issues - the more general issue of whether epidemiology can ever suffice to support any inference of specific causation and the more precise issue of whether the doubling-plus rule should be held to correspond with the preponderance standard for proof of specific causation-all without ever making clear that specific causation was the issue at hand. ${ }^{362}$ This allowed the Havner court to then cast the doubling-plus rule as a compromise position and mistakenly to label it a rule of general causation. ${ }^{363}$

359. See, e.g., Rosenberg, supra note 262, at 859 n.43 (recognizing Estep's work as the "pioneer"); id. at 863 (arguing that the strong version of the preponderance rule, requiring particularistic evidence, results in aggregate underdeterrence while the weak version, allowing recovery whenever relative risk exceeds two, results in aggregate overdeterrence). See also, e.g., Black \& Lilienfeld, supra note 247, at 767 (advocating for doubling-plus rule); Colin Hugh Buckley, A Suggested Remedy for Toxic Injury: Class Actions, Epidemiology, and Economic Efficiency, 26 WM. \& MARY L. REV. 497, 528 n.190 (1985) (describing underterrence/ overdeterrence problem); Palma J. Strand, The Inapplicability of Traditional Tort Analysis to Environmental Risks: The Example of Toxic Waste Pollution Victim Compensation, 35 STAN. L. REV. 575, 583-04, 603-04 (1983) (describing rationale for doubling-plus rule and discussing problems of both all-or-nothing and proportional recovery rules); Mario J. Rizzo \& Frank S. Arnold, Causal Apportionment in the Law of Torts: An Economic Theory, 80 CoLuM. L. REv. 1399, 1402 (1980) (advocating use of "relative causation" as an apportionment tool). Judge Weinstein's fairness opinion in the Agent Orange litigation, "an article . . . that masqueraded as a judicial opinion," might be included in this group as well. Green, supra note 295, at 360 (citing In re “Agent Orange” Prod. Liab. Litig., 597 F. Supp. 740 (E.D.N.Y. 1984), aff'd, 818 F.2d 145 (2d Cir. 1987)).

360. Merrell Dow Pharm., Inc. v. Havner, 953 S.W.2d 706, 714-15 (Tex. 1997).

361. See id. at 715-17.

362. Compare, e.g., id. at 715 (describing opinions holding that "epidemiological studies showing an increased risk may support a recovery") and id. at 716 (noting that some commentators argue "epidemiological studies cannot, standing alone, establish causation"), with id. (describing opinions holding that relative risk must exceed 2.0 and opinions rejecting that threshold), and id. at 717 (describing academic criticism of "attempts by the courts to meld the more than $50 \%$ probability requirement with the relative risks found in epidemiological studies").

363. Id. at 717 (noting that the court was "persuaded that properly designed and executed epidemiological studies may be part of the evidence supporting causation . . . and that there is a rational basis for relating the requirement [of] more than a 'doubling of the risk' to ... the more 
Havner elicited some academic commentary, including some criticism. ${ }^{364}$ But Havner's misapplication of the doubling-plus rule to general causation garnered little attention. This was entirely understandable. The Havner court did not express itself clearly. It used an illustration that fit perfectly with the use of doubling-plus as a proxy for "more likely than not" specific causation. For the most part, among the community of scholars that thinks about these issues, Havner stood as just another example-albeit in some ways an extreme example - of a court opinion using the doubling-plus rule in a familiar way-to address the problem of specific causation for non-signature diseases that may be caused by toxic exposures. ${ }^{365}$

And yet the unremarked reference to general causation in Havner reverberated, as described above, in Texas jurisprudence as case law evolved. As we have seen, it undermined the coherence of that jurisprudence and left Texas courts, including the supreme court itself, confused about the meaning of specific causation and of general causation as well. It facilitated the shifts in causal models that led to the internally inconsistent holdings of Bostic. And ultimately it led to Bostic's most egregious error, requiring independent causal sufficiency for each tortious source of toxic exposure.

Of course, there is no telling whether academic commentary would have changed the course of the Supreme Court of Texas. Since Havner, the court has not again conducted a canvass of the scholarly literature on toxic torts. The court cited few sources from that literature in Flores, none at all in Garza, and only two (not counting Restatement sections) in the majority opinion in Bostic. Nevertheless one can hope that a scholarly response might prompt rethinking, in Texas or in courts elsewhere that might be tempted to emulate the reasoning of a majority of the highest court in the nation's second most populous state. ${ }^{366}$ This

likely than not burden of proof"); id. at 718 (describing holding as a "balance" between conflicting norms).

364. E.g., Finley, supra note 2, at 362 (criticizing Havner for making a policy judgment in the guise of a scientific reliability ruling).

365. E.g., Danielle Conway-Jones, Factual Causation in Toxic Tort Litigation: A Philosophical View of Proof and Certainty in Uncertain Disciplines, 35 U. RICH. L. REV. 875, 905 (2002) (describing Havner as embodying a "general-specific causation plus" test); Andrew R. Klein, Rethinking Medical Monitoring, 64 BROOK. L. REv. 1, 20-21 (1998) (citing Havner, among other examples, as use of the doubling-plus rule for specific causation, in an article advocating that plaintiffs should receive medical monitoring damages only on showing tortious exposure that more than doubles the risk of disease); Vern R. Walker, Restoring the Individual Plaintiff to Tort Law by Rejecting “Junk Logic” About Specific Causation, 56 Ala. L. ReV. 381, $472-73$ (2004) (describing Havner's doubling-plus rule as a specific causation rule); but see Thomas O. McGarity, Proposal For Linking Culpability And Causation To Ensure Corporate Accountability For Toxic Risks, 26 WM. \& MARY EnVTL. L \& POL'y Rev. 1, 24 (2001) (citing Havner as one of several courts that "read the Daubert remand opinion to conclude that an epidemiological study demonstrating a relative risk of greater than 2.0 is in fact the minimum showing necessary to prove general causation").

366. To date Bostic has been little cited outside Texas, but at least some courts have taken 
article may prompt some of that thought.

\section{CONCLUSION}

Toxic tort cases involving multiple exposures are not easy. They present challenging issues of factual causation and competing policy considerations.

The policy considerations, which are largely beyond the scope of this article, may be particularly acute for carcinogens like asbestos which can cause serious illness after low levels of exposure and which are or have been ubiquitous in workplace and consumer settings. In the case of asbestos, courts' policy judgments may also be influenced by the sense that the most culpable parties have long since been judgment-proof ${ }^{367}$ However, if policy concerns are to drive courts' decision-making in such cases, courts ought to express openly their policy judgments and their rationales, rather than casting those judgments as matters of causation-in-fact.

The factual causation issues are difficult but not intractable. Some courts in the United States and the United Kingdom have successfully turned to a risk contribution model of causation, ${ }^{368}$ eschewing the doubling-plus rule. ${ }^{369}$ A risk contribution model does not necessarily mean that plaintiffs always prevail; it can leave room for policy-based exceptions for de minimis contributions to overdetermined harm and for apportionment of liability in appropriate cases. This model, although imperfect, has considerable merit and comports reasonably well with existing scientific understanding of mesothelioma causation by asbestos. ${ }^{370}$

The fundamental problem with the majority opinion in Bostic is that the majority recognized the appropriateness of a risk contribution model but refused to apply it. Instead, perhaps to serve policy objectives, the Bostic majority misused a hodgepodge of causal models to produce factual causation rules at odds with tort doctrine and common sense. That is a mistake that legal scholars should note and that other courts should decline to replicate.

note. See, e.g., In re N.Y. City Asbestos Litig., 2015 WL 1840006, at 21 n.1 (N.Y. Sup. Ct. Apr. 13, 2015) (favorably citing Bostic and Ford Motor Co. v. Boomer, 736 S.E.2d 724 (Va. 2013)).

367. See Sanders, supra note 11, at 1156.

368. E.g. Sienkiewicz v. Greif, [2011] UKSC 10, [2011] 2 WLR 523 (appeal taken from Eng.); Rutherford v. Owens-Illinois, 941 P.2d 1203, 1220-21, 1223 (1997).

369. E.g., Sienkiewicz, [2011] UKSC 10 [105], [2011] 2 WLR 523 (appeal taken from Eng.) (Lord Phillips) (giving hypothetical of several exposures that combine to more than double risk in rejecting doubling-plus rule for individual exposures); Allen v. United States, 588 F. Supp. 247, 416-18 (D. Utah 1984) (rejecting doubling-plus as minimum threshold for substantial contribution to harm); Rutherford, 941 P.2d at 1220 (holding that in risk contribution context, the "substantial factor standard is a relatively broad one, requiring only that the contribution of the individual cause be more than negligible or theoretical").

370. For an exploration of potential difficulties with the risk contribution approach, see Sanders, supra note 41, at 36-40. For an argument in favor of the approach, see Gold, supra note 85 , at $322-38$. 